\title{
Acordos Administrativos e sua Validade no Brasil.
}

\author{
Guido Fernando Silva Soares \\ Professor Assistente Doutor de Direito Internacional \\ na Faculdade de Direito da Universidade de São \\ Paulo e de Política na Pontifícia Universidade \\ Católica de São Paulo
}

\begin{abstract}
SUMÁrio: I. Introdução. II. Política Exterior no Constitucionalismo Liberal. III. Os Acordos Administrativos. IV Contratos Administrativos Internacionais. V Direito Comparado. VI. Acordos Administrativos e as Anteriores Constituigões Brasileiras. VII. Acordos Administrativos e a Constituição Vigente. VIII. Do Poder Regulamentar no Direito Internacional. IX. Bibliografia.
\end{abstract}

\section{Introdução.}

Os acordos administrativos são de extrema importância nos dias atuais, em especial no campo da transferência internacional de tecnologia, campo em que os Poderes Executivos dos Estados se mostram suficientemente dinâmicos para, de um lado, encamparem reivindicações e necessidades dos cidadãos sob sua tutela, e de outro, eles próprios, nas formas de administração descentralizada, integrarem relações jurídicas extremamente técnicas e sofisticadas. Tendo o homem passado já por duas idades da produção, segundo ANDRÉ SIEGFRIED, a idade pré-industrial do instrumento movido pelo seu músculo, e a idade mecânica, em que aprendeu a utilizar, ilimitadamente, as energias da natureza a seu serviço, encontra-se, no momento, no interior mesmo do que denomina a idade administrativa, onde a empresa tende a escapar, cada vez mais, do indivíduo, "seja no que respeita sua propriedade, seja sua direção" $1 *$

* Os textos em língua estrangeira foram livremente traduzidos pelo autor.

1. ANDRE SIEGFRIED, Le Problème de l'Etat au $\mathrm{xx}^{\theta}$ Siècle en fonction de la production in Politique et Technique, Centre de Sciences Politiques de l'Institut D'Études Juridiques de Nice, Université d'Aix-Marseille, Paris, 1958, P.U.F., p. 15. 
Tempo em que a fabricação técnica se simplifica, e dá causa a que a gestão das empresas se torne cada vez mais complexa, "o Estado, transformado em industrial, se vê obrigado a raciocinar, reagir, comportar-se como um industrial, o que é, para ele, um ângulo de visão inteiramente novo". "A indústria, de seu lado, que tende a transformar-se numa espécie de serviço público, deve levar avante suas relações com a Comunidade, realizando administração (pública) diplomacia, política, quase mesmo, propaganda eleitoral" 2. É evidente que tal clima conducente a um intervencionismo estatal crescente, nascido da "industrialização do mundo que levou as autoridades públicas a resolver problemas cujos dados são totalmente fornecidos pela técnica" ${ }^{3}$, propiciaria transformações fundamentais na estrutura jurídico-política dos Estados e no seu relacionamento com o exterior. Claro se torna que, numa época permeada de tecnologia, e em que a Administração do Estado se organiza (e assim pode fazê-lo, pela sua flexibilidade institucional) a fim de enfrentar novas realidades, surja um descompasso em relação ao Legislativo, em especial no modelo arquitetado por MONTESQUIEU, cujo fortalecimento foi concebido, exatamente para limitar o Executivo. Se de um lado o Poder Executivo pode contar com a colaboração crescente de técnicos, dotando-se de uma infra-estrutura burocrática altamente especializada, o Legislativo continua com suas atribuições tradicionais, de ser órgão de representação política, da nobre missão de traçar as grandes linhas políticas do Estado, mas, despreparado para enfrentar questões urgentes, técnicas e que exigem a colaboração de especialistas, nem sempre à disposição para esclarecer os representantes do povo. Se no esquema do Estado liberal, "gendarme" a participação do Legislativo na elaboração das normas era a regra, no Estado intervencionista, "welfare", onde é empresário, banqueiro, transportador, médico, empregador, produtor direto de bens de consumo, sua participação se torna um esbarro à dinâmica do Governo. Tais fenômenos se refletem, de igual modo, na ação exterior do Estado, em especial, nas atividades que requerem a participação conjunta do Executivo e do Legislativo.

2. A. SIEgFried, id, ibid, p. 17 "l'industrie... doit menager ses relations avec la communauté, c'est-à-dire faire de l'administration, de la diplomatie, de la politique, presque de la propagande électorale".

3. Marcel Merle, L'Influence de la Technique sur les Institutions Politiques, in Politique et Technique id, ibid., p. 37. 


\section{Política Exterior no Constitucionalismo Liberal.}

2. Formados os Estados modernos, com sua base territorial fortemente assentada (territorialidade das leis) e com o poder personificado na figura do monarca, as relações exteriores no Absolutismo eram conduzidas por este, a seu talante, sem quaisquer considerações pelos anseios populares. $O$ povo, embora fosse o grande esteio dos exércitos reais, em épocas de guerras importantes, convocado à força para integrar batalhões sustentados pela fortuna pessoal do monarca, participava das expedições militares, sem qualquer entusiasmo cívico, uma vez que estas eram destinadas a resolver assuntos quase que domésticos, ligados a interesses das famílias reais. Dotes, casamentos, questões hereditárias eram assuntos que, se relativos a algum monarca, se transformavam em questões pertinentes ao próprio Estado, ensejando, assim, a guerra entre os povos. Por outro lado, desfeito o mundo medieval de uma "communitas christiana", e, portanto, desaparecidas a figura do Imperador, como defensor da cristandade contra os inimigos externos, e a figura do Papa, como árbitro para as desavenças internas, assim como tendo havido a Reforma como elemento desaglutinador do universo unificado na existência de uma família reinante cristã e com pretensões universais (os Habsburgos), houve a necessidade para as novas unidades políticas, os Estados, de elaborarem novas formas de relacionamento entre eles; por tais razões, a teoria dos tratados internacionais ganha relevo, no sentido de substituir por esquemas negociados entre as partes, o que antes era conseguido por negociações entre irmãos da mesma comunidade de valores.

3. "Como conseqüência do impulso da expansão imperialista, que recheia esta época, os tratados internacionais modificaram seu conteúdo e finalidade; já não tendiam tanto à conservação da paz, mas eram negociados, tendo-se em conta as guerras projetadas ou as que se consideravam invitáveis" 4 . Desenvolveu-se um princípio de equilíbrio entre os Estados (Paz de Utrech de 1713) pelo quál, "nenhum Estado há de poder chegar a ser tão poderoso que esteja em condições de só, ou em união com seus aliados, impor sua vontade aos demais" 5 . Substituída a idéia de comunidade pela de um mecanismo de

4. Georg Stadtmüller, História del Derecho Internacional Público, Parte I, Madri, Aguilar, 1961, p. 156.

5. Alfred Verdross, Derecho Internacional Público, Madri, Aguilar, 5. ${ }^{\text {a }}$ Ed., 1967, p. 36. 
equilíbrio, o direito internacional seria modificado para atender a tal. Soberanos, incontrastáveis na sua vontade, os Estados poderiam dispor livremente de seus territórios, interpretariam, bona fide, o direito internacional na sua exclusiva jurisdição e a antiga teoria da guerra justa se dilui para dar lugar à teoria da autotutela e da razão do Estado.

4. O que é de suma importância notar é que os tratados, como quaisquer contatos diplomáticos entre Estados, eram de responsabilidade pessoal do monarca. Os negociadores eram pessoas de confiança dos monarcas e o direito de representação exterior pertencia à família reinante e não ao Estado. As relações familiares entre os monarcas causavam, por vezes, profundas modificações territoriais, o que faz com que Kant, no ensaio Sobre a Paz Perpétua, se perguntasse como é que pessoas morais, como os Estados, poderiam contrair matrimônios, levar dotes, prometer doações! Até a Revolução Francesa, foi intensa a atividade diplomática e os costumes nas cortes foram, aos poucos, criando um direito diplomático com reflexos no direito dos tratados. Em 1789, praticamente já estavam formados os princípios das negociações de tratados internacionais, que eram bastantes freqüentes, e tinham por finalidades, alianças, a base do sistema, convênios comerciais, garantias recíprocas possessórias, cessões e divisões de territórios, intervenções diplomáticas ou militares. "O término da guerra, mediante a conclusão da paz, se levava a cabo de forma solene, de acordo com a singular importância atribuída nessa época aos tratados internacionais" ${ }^{6}$, pois representavam eles a palavra empenhada do próprio monarca.

5. Também no campo dos tratados internacionais a Revolução Francesa viria a dar sua inestimável contribuição, ao reformular o princípio da representatividade exterior dos Estados. Na verdade, segundo G. STADTMÜLLER, "as idéias de Iluminismo relativas à igualdade universal, aos direitos do homem e ao contrato social como fundamento jurídico do poder do Estado, originarão a teoria da soberania do povo, segundo a qual, a soberania, isto é, a ilimitada capacidade de agir jurídico-política e internacional não correspondem a um soberano ou a uma aristocracia, como classe dirigente dotada de privilégios políticos, mas sim à população do Estado, como conjunto" ?. Por outro lado, as guerras por motivos dinásticos,

6. G. Stadtmüller, id., p. 207.

7. G. Stadtmüller, id., p. 221. 
sua impopularidade, e a necessidade de desvincular a política exterior da pessoa do monarca, forçaram a adoção dos princípios do controle parlamentar de tais atividades. As primeiras Constituições baseadas nas idéias do Iluminismo viriam a consagrar expressamente os princípios da plena liberdade do Executivo em matéria de relações exteriores dever ser cerceada pelos representantes populares. Com efeito, a primeira constituição escrita, a dos Estados Unidos da América, "expressis verbis" declara: "Ele (o Presidente) terá o poder, após consulta e consentimento do Senado, de concluir tratados, na condição de haver maioria de dois terços de senadores presentes; designará e, após consulta e consentimento do Senado, nomeará os Embaixadores, e outros ministros públicos, os cônsules ... (Art. II, sec. $\left.2, \S 2 .^{\circ}\right)^{8}$. A Constituição Francesa de 1791, claramente, em duas ocasiões, dispõe sobre a necessidade da aprovação do Legislativo dos tratados assinados pelo Executivo: art. $3^{\circ}$, Sec. Primeira, Cap. III (É da competência do Corpo Legislativo ratificar os tratados de paz, de aliança e de comércio; e nenhum tratado terá efeito senão através desta ratificação) e art. 3. ${ }^{\circ}$, Sec. III, Cap. IV (Compete ao Rei decretar e assinar com quaisquer potências estrangeiras, todos os tratados de paz, de aliança e de comércio, e outras convenções que julgar necessárias ao bem do Estado, através da ratificação do Corpo Legislativo) ${ }^{9}$.

6. Se a partição do poder de subscrever tratados foi uma novidade constitucional revolucionária, trouxe ela complicações na esfera das relações externas dos Estados. Relembre-se que a teoria da divisão dos poderes do Estado que foi adotada nas Constituições modernas, foi a de MonTEsquieu, que, a fim de

8. Verbis: "He shall have Power, by and with the Advice and Consent of the Senate, to make Treaties, provided two thirds of the Senators present occur; and he shall nominate, by and with the Advice and Consent of the Senate, shall appoint Ambassadors other Public Ministers and Consuls... (texto apud Louis Henkin Foreign Affairs and the Constitution, Nova York, W. W. Norton \& Co. Inc., 1. ${ }^{\mathrm{a}}$ Ed., 1972, copyright da Foundation Press, Inc.).

9. Art. $3 .^{\circ}$, Sec. II, Cap. III, verbis: "Il appartient au Corps législatif de ratifier les traités de paix, d'alliance et de commerce; et aucun traité n'aura effet que par cette ratification". Art. $3 .^{\circ}$, Sec. III, Cap. IV, verbis: "Il appartient au Roi d'arrêter et de signer avec toutes les puissances étrangères tous les traités de paix, d'alliance et de commerce, et d'autres conventions qu'il jugera nécessaires au bien de l'Etat, sauf la ratification du Corps législatif". (Textos apud Maurice Duverger Constitutions et Documents Politiques 6a. Edi., 1971 (1.0 Trimestre) Paris, Presses Universitaires de France, respectivamente, ps. 23 e 28. 
separar a titulariedade do poder, como expediente de controlá-lo, imaginou os Poderes Executivo, Legislativo e Judiciário. A teoria de LOCKE, que serviu de base à de MoNTESQUIEU seria colocada de lado; ora, segundo esta, o Poder estaria dividido entre Executivo, Legislativo e Federativo, este, o poder de representação exterior dos Estados, constituído de um monobloco, independente da configuração democrática ou não do Estado e, sobretudo, contínuo, enquanto existir o Estado. A continuidade da política exterior dos Estados exigiu que se elaborassem instituições novas, compatíveis com as organizações constitucionais modernas, onde o poder interno dos Estados se encontra dividido por entre titulares diversos. A questão dizia, em especial respeito, à legitimação dos signatários de tratados e à concordância do poder popular com os atos assinados pelo Poder Executivo. Apareceram, por prática diplomática, assim, na sistemática dos atos internacionais, as instituições dos plenos poderes e da ratificação pelos signatários dos tratados, esta, pressuposto de que os poderes legislativos do Estado teriam dado seu assentimento ao mesmo. A participação obrigatória do Legislativo na feitura da lei e do tratado, teria importantes conseqüências no próprio desenvolvimento do direito dos tratados, em particular no que respeita sua vigência interna e internacional.

\section{Os Acordos Administrativos.}

7. A teoria clássica dos tratados tal como saída do espírito revolucionário de 1789, afirmava serem eles atos complexos, que se originavam de negociações entre Executivos dos Estados, levadas a cabo por agentes diplomáticos, cuja capacidade de negociar em nome do Estado, conquanto baseada em normas internas, era demonstrada e tida como legítima, bona fide, pela simples exibição dos plenos poderes do signatário, o que fazia pressupor, sua adequação às normas domésticas. 0 tratado seria aperfeiçoado e teria seu começo de vigência, no momento em que os signatários trocassem os instrumentos de ratificação, ato que significaria ter o tratado sido aprovado pelos poderes constitucionais do Estado e, ao mesmo tempo, ter entrado em vigência na esfera interna. O importante a observar é que a ratificação tornaria possível a apresentação de reservas ao texto, nascidas de alguma discordância do Legislativo ao tratado negociado pelo Executivo. A prática da ratificação entrou para o direito internacional, não sem trazer alguns inconvenientes, tais como a demora na entrada em vigor 
de um tratado, as incertezas que possíveis reservas feitas pelo Legislativo podem criar no momento mesmo das negociações, bem como o trazimento de questões internas (legitimação dos agentes diplomáticos, exercícios dos poderes de negociação nos exatos limites de delegações de poderes entre Executivo e Legislativo para a conclusão de tratados, etc.) para uma esfera do direito internacional, onde as relações jurídicas se dão, no princípio da boa fé dos agentes, suas competências, sua legitimidade estando, salvo prova em contrário, conforme às leis.

8. Nesta ordem de considerações, "a lentidão tornou-se um apanágio desse procedimento (aprovação legislativo-parlamentar dos tratados) e influía decisivamente para a alta taxa de mortalidade infantil dos tratados internacionais ${ }^{10}$. Em contraste com tal fenômeno, o aperfeiçoamento das telecomunicações e a instituição de organismos internacionais com representação estatal permanente (diplomacia parlamentar), bem como a reiterada prática de contatos diretos entre chefes de Estados (diplomacia de cúpula), devidos aos progressos nos meios de transportes, tornariam obsoletos os princípios de entrada em vigência dos tratados internacionais. Por outro lado, a complexidade dos assuntos internacionais, a necessidade de regulamentar na esfera exterior da ação política dos Estados determinados assuntos técnicos (científicos e tecnológicos) ou ainda, deixar à ação de funcionários administrativos a execução de tarefas menores, cujos objetivos já estariam fixados em atos solenes anteriores, causaram "um esvaziamento das normas constitucionais referentes à participação do parlamento na conclusão dos acordos internacionais, (surgindo) então os acordos em forma simplificada" ${ }^{11}$, também denominados acor-

10. JoÃo Grandino Rodas, Os Acordos em Forma Simplificada in Revista da Faculdade de Direito, v. $6810^{\circ}$ fasc.) 1973, Universidade de São Paulo, São Paulo, p. 319.

11. João Grandino Rodas, id., p. $319 / 320$.

11. bis. Note-se que pode haver confusão entre "Executive Agreement" e "Gentlemen's Agreement", este, sinônimo de "Honourable Under-standings". Observa H. KRaUs apud Système et Fonctions des Traités Internationaux in Recueil des Cours da Academia de Direito Internacional da Haia, 1934, v. 50, p. 329 , a respeito de "Gentlemen's Agreement": "sob esta denominação que, por infelicidade, na prática dos ministérios dos negócios exteriores é muitas vezes empregada igualmente para os acordos administrativos que são, estes sim, verdadeiros tratados internacionais, se dissimulam acordos entre funcionários do poder exterior, acordos que obrigam somente tais indivíduos, moralmente e a título pessoal, mas não seus Estados" 
dos administrativos, ou ainda "Executive Agreements". Com suficiente perspicácia, o Professor J. GRANDINo Rodas! faz notar que "enquanto os textos constitucionais eram burilados pela teoria da maior democratização, na formação dos acordos internacionais, despontavam paradoxalmente, os acordos concluídos sem a intervenção formal do parlamento" ${ }^{12}$.

9. De formação consuetudinária, segundo PAUL DE VISSCHER, integraram costumes internacionais, a tal ponto, que modernamente, textos constitucionais se referem claramente aos acordos administrativos. A doutrina aponta, no geral, que "a existência mais que secular da prática, a ausência de toda distinção articulada, expressa formalmente, entre os acordos executivos, fundados sobre o seu procedimento ou objeto; a aceitação pelos governos e congressos sucessivos das obrigações internacionais assumidas nessas condições, parece ser uma garantia suficiente de constitucionalidade" ${ }^{13}$. Por outro lado, a Convenção de Viena sobre Direito dos Tratados, de 1969, conquanto não vigente, é uma notável compilação de costumes diplomáticos, e nela, o art. 11 consigna os "meios de manifestar consentimento em obrigar-se por um tratado:" o consentimento de um Estado em obrigar-se por um tratado pode ser manifestado pela assinatura, troca dos instrumentos que constituem o tratado, ratificação, aceitação, aprovação ou adesão, ou por qualquer outros meios, se assim for acordado". No que respeita à entrada em vigor dos tratados, a mesma Convenção de Viena dispõe no art. $24, \S 1 .^{\circ}$ que "um tratado entrará em vigor na forma e na data prevista no tratado ou acordada pelas partes" e $\S 2 .^{\circ}$, que "na ausência de tal disposição ou acordo, um tratado entrará em vigor tão logo o consentimento em obrigar-se por um tratado for estabelecido por todos os Estados negociadores". Portanto, para o Direito Internacional, e nisso há substancial doutrina a respeito, em especial, BALLADORI PAllieri, La Formation des Traités dans la Pratique Internationale Contemporaine (Recueil des Cours, da Academia Internacional da Haia, 1949 , v. I, tomo 74 , p. 471/545), a validade de um tratado internacional, bem como sua vigência, devem ser buscadas nas normas de Direito Internacional, na

12. João Grandino Rodas, id., p. 320 .

13. Roger Pinto, La Reforme du Congrès, in Revue du Droit Püblic et de la Science Politique, Lib. Gén. du Droit et de Jurisp., Paris, 1950, tomo 66, p. 378, citus apud, e com tradução de JoÃo Grandino RodAS, id., p. 322. 
intenção das partes, e não meramente nas disposições dos direitos constitucionais internos.

10. "Menos solenes e mais adaptados ao desenvolvimento crescente das relações internacionais, notadamente no domínio das técnicas de ponta" ${ }^{14}$ os acordos administrativos se opõem ao tratado, entendido este como "um acordo com a mais solene forma, comportando a intervenção da mais alta autoridade encarregada das relações internacionais, de ordinário, o chefe de Estado..." 15. "Normalmente distinguem-se pela ausência de alguma das características dos tratados em devida forma" ${ }^{16}$, seja pela forma simplificada de entrada em vigor, simples negociação e assinatura, (portanto dispensa da aprovação parlamentar e posterior troca dos instrumentos de ratificação), seja pela dispensa da "intervenção de plenipotenciários habitualmente mandatários para tal efeito ${ }^{17}$, seja ainda os "concluídos por um órgão ao qual a constituição, "expressis verbis", não concede o "treaty making power" 18 , ou ainda, os que dispensam a ratificação, mas cujo conteúdo se encontra limitado pelas Constituições, ou finalmente, os de conteúdo delimitado na Constituição, que dispensam ratificação, mas que devem ser aprovados pelos parlamentos.

\section{Contratos Administrativos Internacionais.}

11. A doutrina generalizada do Direito Internacional Público ensina que a denominação de um ato internacional pouco afeta sua natureza, pois, o que importa é a intenção das Altas Partes Contratantes. Pode dar-se o caso de um mesmo ato internacional ser denominado, em línguas diferentes, de maneiras diversas. Por outro lado, há igual concordância universal, de que não existem diferenças entre denominações tratado, convênio, acordo, ajuste, protocolo, ato, etc., que de-

14. EMMANUEL LIBBRECHT, Entreprises à Caractère Juridiquement International, 1a. Ed., A.W. Sijthoff e Institut Universitaire de Hautes Etudes Internationales, respectivamente, Leiden e Genebra, 1972, p. 37.

15. J. BASDEVANT, La Conclusion et la Rédaction des Traités Internationaux et des Instruments Diplomatiques autres que les Traités" in RECUEIL DES CoURS da Academia de Direito Internacional da Haia, t. 17, 1926, p. 542 e ss.

16. JoÃo GrandiNo Rodas, id., p. 324.

17. E. LIBBRECHT, id., p. 38.

18. LUziUs Wildhaber, Treaty making Power and Constitution; an International and Comparative Study, Basiléia, Helbing \& Lichtenhahn, 1971, citus apud e com tradução de João Grandino Rodas, id., p. 325. 
terminem seu conteúdo, pela simples designação. Isto posto, e tendo presente que a Convenção de Viena sobre o Direito dos Tratados, os define como um acordo ("agreement") em forma escrita e regidos pelo Direito Internacional, cumpre distinguir nos acordos internacionais, seja os em devida forma, seja os em forma simplificada (acordos administrativos), 2 tipos segundo TRIEPPEL: a) tratados-leis, (Vereinbarungen) que são aqueles atos que criam um sistema geral de direitos e obrigações entre as partes, sem que haja uma exata correspondência entre as prestações exigíveis e devidas, p. x.: um tratado de amizade e consulta, de instituição de organismo internacional ou de outras formas associativas, de comércio e navegação etc., e b) tratados-contratos (Vertragen), que são atos sinalagmáticos e comutativos, ou seja, em que a prestação exigível por uma parte tem uma correspondência à prestação devida pela outra, p.ex. : tratado que institui um financiamento entre Estados, que transfere tecnologia ou material militar sob condição de determinadas ações militares, que institui mecanismos de compensações no balanço de pagamentos etc. Ora, se a denominação pouco importa, havendo mesmo algumas que pertencem tanto à teoria dos tratados, quanto a dos contratos (acordos, ajustes, igualmente confusas nas atuais línguas francas da comunidade internacional: agreement, compact; accord, convention; soglachenie etc.), haveria de ser encontrada, alhures, outro critério para distinguir os acordos administrativos, dos contratos administrativos internacionais.

12. Diz a doutrina inglesa: "os Estados podem... fazer acordos (agreements) entre si, que são regidos por algum direito nacional e não pelo direito internacional. Tais acordos são utilizáveis em casos, por exemplo, de venda de mercadorias ou armamentos, ou empréstimo de propriedade, quando terceiros não submetidos ao direito internacional estão intimamente envolvidos na transação. Embora tais acordos sejam, num certo sentido, "internacionais", não são regidos pelo direito internacional, não são tratados (treaties) mas contratos de Estado (State contracts)" 19. A tais afirmações, algumas ponderações são necessárias: a) se existe a admissão de que tais acordos são regidos por algum direito nacional, na presunção de que existe plena autonomia da vontade nos contratos internacionais, nada impede que as partes "deslocalizem" os

19. N. A. MARyan Green, International Law, Law of Peace, Londres, MacDonald \& Evans Ltd., 1973, p. 161/162. 
contratos e os façam regidos por um direito transnacional ${ }^{20}$, que legitime as normas contidas nos próprios contratos ${ }^{21}$; b) no caso de as partes num contrato serem Estados, nada impede que, por uma cláusula de eleição da lei a ele aplicável, escolham o Direito Internacional Público, se não houver particular diretamente envolvido no negócio; c) os "State contracts", se não envolverem particulares, são regidos ipso jure, pelo Direito Internacional Público, pois há questões de soberania envolvidas, de legitimação dos signatários (abuso de poderes de representação), de responsabilidades por inadimplemento etc.

13. Descartando-se, na relação jurídica, da presença de particulares (pois, em definitivo, não podem ser parte em uma relação regida pelo Direito Internacional Público), as relações de Estado a Estado são sempre regidas pelo Direito Internacional Público, sejam tais relações oriundas de um acordo em forma simplificada, que dispensa a aprovação dos Legislativos internos, seja de um contrato (que, em certos casos, dispensam a aprovação do Legislativo ou de uma seção do mesmo). Quanto ao contrato administrativo internacional, mesmo que as Altas Partes Contratantes elejam como lei aplicável, a de uma delas ou de um terceiro Estado, não poderão totalmente descartar-se da aplicação do Direito Internacional, a exemplo, de sua imunidade de jurisdição dos tribunais internos, privilégio esse que poderá sempre ser invocado e cuja desistência não pode ser presumida (e se houver desistência de imunidade, acontece por permissividade do próprio Direito Internacional Público).

20. Seria este um direito a meio caminho entre os direitos nacionais e o internacional, conforme JEAN-FLAvIE LALIVE in Contracts between a State or a State Agency and a Foreign Company, 13 Intl. and Comparative Law Quartely, julho, 1974, p. 1002 ss. Caracterizar-se-ia por aplicar a partes juridicamente desiguais (relações entre Estados e particulares estrangeiros), regras forjadas a partir do Direito Internacional Público (que desconhece a teoria dos contratos) e da Teoria Geral dos Direitos, (teoria geral dos contratos, como um sistema próprio, presente em quaisquer legislações e auto-aplicável).

21. Na sentença arbitral proferida no Caso Governo da Arábia Saudita versus Aramco, o tribunal arbitral, à falta de indicação da lei aplicável a uma concessão petroleira dada por aquele Governo a um consórcio privado norte-americano, "deslocalizou "o contrato de concessão", fazendo-o regido pelos princípios gerais do direito. Vide, do autor, Concessões de petróleo e arbitragens internacionais: o Caso Aramco e o Caso Sapphire, xerox, Biblioteca do Departamento de Direito Internacional da Faculdade de Direito da USP (texto para uso dos alunos da disciplina: Técnica das Negociações das Arbitragens e das Soluções Pacíficas de Controvérsias), 1976. 
14. Isto posto, o único critério distintivo entre acordos administrativos e contratos administrativos internacionais parece ser o de que, nos primeiros, ipso jure, se aplica o Direito Internacional Público; nos segundos, há permissividade de eleição de lei aplicável, bem como de prorrogação ou derrogação do foro de uma das Altas Partes Contratantes, permissividade essa sujeita às normas do Direito Internacional Público. Note-se que mesmo a interveniência de um particular numa relação contratual com um Estado, ou "a fortiori", entre Estados, não descaracteriza a necessidade da virtual invocação das normas do Direito Internacional Público, exatamente porque uma das partes é um Estado, conforme precedentes fixados em arbitragens internacionais ${ }^{22}$ ou da elaboração de normas que não se despregam totalmente daquelas.

15. Num Estado de organização federativa, a questão se torna ainda mais importante, no que respeita à distinção do que seja contrato administrativo internacional e os acordos administrativos. Os Estados-membros o Distrito Federal e os Municípios, segundo o Direito Internacional Público, não podem, numa Federação, assinar acordos administrativos, pois não têm personalidade de direito internacional público, ou seja, não tem legitimidade para obrigarem-se por tratados ainda que, em forma simplificada. No Brasil, a Constituição Federal vigente (Emenda n. ${ }^{\circ} 1 / 69$ ), no Art. 42, IV dá ao Senado Federal a competência privativa de "autorizar empréstimos, operações ou acordos externos, de qualquer natureza, de interesse dos Estados, do Distrito Federal e dos $\mathrm{Mu}-$ nicípios, ouvido o Poder Executivo Federal", sem se mencionar a União. Se comparadas com o Art. 81, x do mesmo texto constitucional (competência privativa do Congresso Nacional de referendar os "tratados, acordos e atos internacionais" celebrados pelo Presidente da República) as disposições do Art. 42, IV dizem respeito a contratos administrativos internacionais, assinados diretamente pelos Estados-membros, Distrito Federal ou Municípios, tão-somente, pois os acordos administrativos (Executive Agreements) são de competência da União. No caso daqueles assuntos mencionados no Art. 42, IV revestirem a forma de acordos administrativos (Executive Agreements), deverá o Poder Executivo Federal, que também

22. Ademais do Caso Aramco, outro é elucidativo nesse sentido: o Caso NIOc versus Sapphire International Petroleums Ltd. Vide nota anterior. 
é o Chefe da Diplomacia, do Poder de Representação Externa (do Poder Federativo, segundo Locke), consultar previamente o Senado Federal, antes de iniciar as negociações ${ }^{23}$.

\section{Direito Comparado.}

16. Nos EUA, responsáveis pelo aparecimento da expressão sinônima Executive Agreements, a doutrina aponta ser elevado o número de acordos administrativos, cuja prática vem mesmo dos tempos de George Washington. A Constituição norte-americana no Art. II, Sec. 2, Par. 2, dispõe ter o Presidente o poder de ajustar tratados ("treaties"), mediante parecer e acordo do Senado, os quais deverão ser aprovados por dois terços dos Senadores presentes. Ora, antes mesmo da entrada em vigor da Constituição, na época votada em Filadelfia em 1787, JoHN JAY no Federalista $n^{\circ} \quad 64^{24}$, escreveria que "tais matérias que nas negociações usualmente requerem o maior sigilo e a maior diligência são as medidas preparatórias e auxiliares que não são importantes à vida da Nação, como tendem a facilitar atingir-se os objetivos da negociação. Para tais matérias, o Presidente não encontrará dificuldade em tomar providências; e se alguma circunstância ocorrer, que requeira parecer e acordo do Senado, poderá a qualquer tempo convocá-lo" ${ }^{25}$. No Federalista $n 0^{\circ} 75$, HAMILTON, sem expressamente dizê-lo, revive a teoria de JoHN LOCKE de que a atividade de firmar tratados, pertence a um poder distinto, nem ao Executivo, nem ao Legislativo (LockE diria: ao Poder Federativo). Expressis verbis HAMILTON declara que "as qualidades que foram reveladas em detalhes como indispensáveis na condução de negociações exteriores, indicam o Executivo como o mais adaptado agente em tais transações; enquanto a vasta importância de dar-se o crédito

23. Isso, na hipótese de admitir-se a possibilidade de existirem acordos administrativos conforme a Constituição Federal Brasileira, segundo será examinado a seguir.

24. The Federalist foi a obra resultante do agrupamento de artigos publicados nos jornais de Nova York, a partir de 27 de outubro de 1787, sob o pseudônimo de Publius, de autoria de Alexander Hamilton, James Madison e Jonh JAY, com o objetivo de esclarecer a opinião daquele Estado sobre a Constituição da Federação, que estava para ser votada em Nova York. São considerados o que há de melhor no Direito Constitucional norte-americano. A edição consultada foi a da Mentor Book, The Federalist Papers, The New American Library of World Literature Inc., Nova York, $1 .^{a}$ Ed., 1961, com introdução e indexação de CLinton Rossiter.

25. The Federalist n. ${ }^{\circ} 64$, p. 393 (vide nota anterior). 
e a operação dos tratados como leis, favorecem a participação de todo ou de uma porção do corpo legislativo na tarefa de terminá-los ${ }^{26}$. A doutrina norte-americana distingue dois tipos de "Executive Agreements" a) os acordos assinados pelo Presidente, de vigência imediata, em matérias que requereriam a intervenção do Senado, após ter havido uma delegação de poderes do Congresso ao Executivo (Congressional Executive Agreements) e b) os "Executive Agreements" típicos (Sole Executive Agreements), que a doutrina norte-americana apontava em janeiro de 1969, em cerca de 973, contra 909 tratados na devida forma ${ }^{27}$. Tendo em mente que o sistema norte-americano presidencial admite delegação de poderes do legislativo ao executivo (que o Judiciário tem reconhecido como válida, expressamente, em Sunshine Anthracite COal Co. v.Adkins, 310, Us. 381 (1940), os "Congressional Executive Agreements" podem aparecer de três maneiras: a) por autorização do Congresso ao Presidente para negociar tratados em matérias particulares: relações postais, comércio recíproco, empréstimos internacionais, assistência exterior e reatores nucleares; b) autorizações do Congresso ao Presidente para concluir determinados acordos já negociados, ou vários acordos multilaterais para instituição de organismos internacionais, por exemplo, o Banco Mundial, o FMI etc; c) por aprovação pelo Congresso de legislação ou alocação de fundos na execução de determinadas obrigações internacionais ${ }^{28}$. Conforme observa autor norte-americano, "aceita-se, sem reservas, que o "Congressional-Executive Agreement" é uma alternativa completa para o tratado: o Presidente pode buscar a aprovação de qualquer acordo por resolução conjunta das duas Casas do Congresso, em lugar dos dois terços do Senado". ${ }^{29}$ e observa que tal procedimento de evitar-se o voto majoritário no Senado, tem evitado a morte prematura de importantes tratados. Quanto à prática dos "S.ole Executive Agreements", a jurisprudência norte-americana tem reconhecido sua validade, como decorrentes da atribuição ao Presidente, e somente a ele, de ser o único órgão das relações exteriores do País. No importante caso United States v. Belmont, 301 Us. 324 (1937),

26. The Federalist n. 75 .

27. MCCLuRE, International Executive Agreements: Democratic Procedure under the USA Constitution, citus apud LOUIS HENkIN, Foreign Affairs and the Constitution, Nova York, 1972, W. W. Norton \& Co. Inc., p. 420 (nota 1).

28. Veja-se, sobretudo, Louis Henkin (citado na nota anterior) Cap. VI.

29. LOUIS HeNKIN, op. cit., p. 175. 
a Suprema Corte dos EUA sustentou que "o poder do Governo sobre os negócios externos não é concorrente, mas é atribuído exclusivamente ao Governo nacional. $\mathrm{E}$ a respeito do que se trata no presente caso ${ }^{30}$, o Executivo tem autoridade para manifestar-se como o único órgão daquele Governo" (voto do Presidente da Suprema Corte, Sutherland). Por outro lado, conforme observa HeNkin, "A Suprema Corte não tem considerado qualquer "Executive Agreement" como ultra vires por falta do consentimento do Senado, nem fornecido qualquer direção que possa definir os poderes do Presidente de agir sozinho ${ }^{31}$, evidentemente, em matéria de política exterior. Portanto, segundo a lei norte-americana, os "Executive agreements" são plenamente válidos, constitucionais, e, depois do caso Belmont, foram considerados de igual hierarquia normativa com os tratados em devida forma, suscetíveis de revogarem leis estaduais, uma vez que são "supreme law of the land", expressão típica usada em relação aos tratados com a participação dos dois terços do Senado norte-americano. $\mathrm{O}$ Restatement of Laws, Second, Foreign Relations Law do American Law Institute ${ }^{32}$ distingue 3 espécies de "international

30. Incidentes ocorridos após o reconhecimento da URss pelos rUA. Pelo Acordo Litvinov, a URSs, que tinha tentado reaver fundos existentes em Bancos de Nova York pertencentes a nacionais russos (os tribunais de Nova York não deram ganho de causa a tal pretensão, com o argumento de que era contra a política daquele Estado executar o confisco de bens situados no Estado) cederia aos EUA todas as reclamações da Rússia soviética contra nacionais norte-americanos, inclusive as contas bancárias confiscadas. O Governo federal norte-americano, com base no mencionado Acordo, buscaria a posse para ele mesmo, daquelas contas bancárias, mas as Cortes de Nova York sustentaram que não teria ele melhores argumentos dos que foram avançados pela cedente, a URSS, e que a ordem pública de Nova York ainda impedia a execução. A Suprema Corte revogou a sentença do Supremo Tribunal de Nova York na base de que, com respeito a quaisquer negociações internacionais e pactos, e com respeito às relacões exteriores em geral, as linhas de fronteiras entre Estados-Membros da Federação norte-americana desaparecem. "Para tais feitos, o Estado de Nova York não existe" (apud HENKIN, id., p. 184/185).

31. HENKIN, id., p. 179.

32. O "Restatement, Second, Foreign Relations Law of the United States", 1962, rev. 64 e 65, do American Law. Institute é notável codificação norte-americana de Direito Internacional. A edição consultada foi: "Restatement, Second, Foreign Relations Law of the United States". As Adopted and Promulgated by the American Law Institute, Washington, D.C., May 26, 1962 (Revisions adopted eles "e ainda" a parte da lei interna dos EUA pelas quais se tornam eficazes as and Promuldated by the American Law Institute at Washington, D.C., on May 20, 1964 and May, 20, 1965), St. Paul, Minn., American Law Institute Publishers, 1965. Nele, define-se o Direito Internacional como o aplicável ao Estado ou a organizações internacionais: e que não pode ser unilateralmente modificado por regras do direito internacional...ou que envolve assunto de relevância significativa 
agreements made as executive agreement": a) de conformidade com um tratado (pursuant to a treaty), $\S 119 ; b$ ) autorizado por um ato do Congresso, $\S 120 \mathrm{e}$; c) sem referencial a tratado anterior ou ato do Congresso, portanto, derivados da autoridade constitucional do Presidente, § 121, "em qualquer matéria que, sob a constituição caiba dentro dos poderes independentes do Presidente". No primeiro caso, deve executar as finalidades do tratado (Poder regulamentar, pois) e se considera auto-executável, revogando as leis estaduais e federais, na condição de haver a intenção de ser transformado em lei interna dos EUA $\S \S 141$ e 142 . No segundo, a competência ratione materiae é determinada pelos assuntos que caibam na competência concorrente do Congresso e do Presidente, "salvo quando não permita uma base independente para um ato do Congresso", e também são considerados auto-executáveis, com igualdade normativa no tempo com as leis estaduais e federais. Quanto ao terceiro caso, dos "executive agreements pursuant to President's Constitutional Authority", dispõe o $\S$ 144 do Restatement:

1. um "executive agreement" celebrado pelos EUA sem referência a um tratado ou ato do Congresso, e conforme as limitações do $\S 121$, e que manifestem a intenção de tornar-se eficaz como lei interna dos EUA ao tempo em que passar a obrigar os EUA: a) revoga provisões com ele inconsistente, das leis dos

para suas relações exteriores $\left(\S 1 .^{\circ}\right.$ e $\S 2 .^{\circ} b$ e $\left.c\right)$ (9). Apesar de o Restatement, Second, Foreign Relations Law of the United States afirmar no seu Prefácio de não ser obra de status oficial, enquanto posição dos EUA e nem pretender propor regras de direito, contudo, representa "uma tentativa de afirmar e clarificar o direito existente, internacional e doméstico, nas áreas mencionadas", tornando-se assim, as regras que um tribunal internacional deveria aplicar, na opinião oficiosa do prestigiado American Law Institute, se tivesse de aplicar o direito internacional. Nele define-se no $\$ 115$, o que se entende por "international agreement": "acordo entre Estados ou organizações internacionais, através do qual existe manifestada uma intenção de criar, modificar ou definir relacionamento, sob a égide do direito internacional", e no $\$ 117$, os escopos de tais atos gerais, de limitarem-se a: a) "que a matéria seja de interesse internacional e b) de não contrariarem nenhuma das limitações da constituição, aplicáveis a todos os Poderes dos EUA". Mais claros se tornam os conceitos de agreement (ato genérico) e treaty (ato específico) no $\S 118$ (1) do Restatement considerado: "(Scope of treaty) an international agreement made by the United States as a treaty may deal with any matter as to which the United States has the constitutional power to make an international agreement under the rules stated on § 117"; nos $\S \S$ seguintes, a expressão é "international agreement made by the United States as executive agreement." 
vários Estados (confirmação com os Casos Belmont $e$ Pink) mas b) não revoga disposições com ele inconsistentes, de atos posteriores do Congresso;

2. um "executive agreement" conforme descrito no item anterior, é sujeito às mesmas limitações com respeito aos tratados no $\S 141-3$ (não pode ser auto-exeqüível e ter validade, se envolve ação, que pela Constituição, só pode ser levada avante pelo Congresso) e não legitima base constitucional para uma ação do Congresso, salvo na medida em que possa autorizar o Congresso a agir segundo a "necessary and proper clause" da Constituição (ou seja a retomada da delegação dos Poderes pelo Congresso).

Quanto ao início de vigência de qualquer tipo de "executive agreement", dispõe o $§ 131$ do Restatement:

Um acordo internacional feito pelo Presidente ou pessoa que aja sob sua autoridade, na forma de um "executive agreement", torna-se obrigatório aos EUA e se torna eficaz como lei dos EUA (conforme $\S \S 142$ e 144), a partir da assinatura ou outro ato do Presidente ou seu delegado...

17. Em França, sua Constituição vigente de 4 de outubro de 1958, dispõe no art. $5242^{\circ}$ : " (O Presidente da República) é informado de qualquer negociação tendente à conclusão de um acordo internacional não submetido à ratificação". Por outro lado, o seu art. 53, caput enumera os tratados que não podem ser ratificados ou aprovados senão em virtude de uma lei, e que só entram em vigência após terem sido ratificados ou aprovados: tratados de paz, tratados de comércio, tratados ou acordos relativos a organizações internacionais, os que comprometem as finanças do Estado, os que modificam disposições de natureza legislativa, os relativos ao estado das pessoas e os que comportam cessão, troca ou junção de territórios (estes últimos, ainda segundo o parágrafo $3 .^{\circ}$ do mesmo artigo, dependendo do assentimento das populações interessadas). O Decreto $n .{ }^{\circ} 53.192$ de 14 de março de 1953 (J. O. de 15-III-1953), "relativo à ratificação dos acordos

33. citus apud JeAN Serres Manuel Pratique de Protocole, Editions de L'Arquebuse, 1. ${ }^{\mathrm{a}}$ Ed., Vitry-le-François (Marne), 1965, ps. 304 e ss. 
internacionais" ${ }^{33}$, divide os acordos internacionais não submetidos à ratificação em três categorias: acordos em forma simplificada, os protocolos ${ }^{34}$ e os regulamentos (règlements) internacionais ${ }^{35}$. Os acordos administrativos, que em França se denominam "accords en forme simplifiée", "cobrem quaisquer compromissos (engagements) concluídos entre os Governos e não entre os chefes de Estado, nem estes, nem os plenipotenciários são neles mencionados. são assinados já no fim das negociações... e as formas de estilo mencionam, em geral, os nomes dos Governos comprometidos, o objeto da negociação, o lugar e a data da assinatura. Portanto, em França, não é o Presidente da República, garante da "continuidade do Estado" (art. 5. ${ }^{\circ}$, Const.) e do "respeito dos Tratados" (id) quem assina ou por quem se assinam os acordos administrativos, mas o Primeiro-Ministro ou um escalão administrativo menor. A única restrição à substância dos mesmos se enumera no art. 53 citado, o qual fixa a obrigatoriedade de uma lei que aprove (se o ato internacional for um acordo em forma simplificada) ou autorize a ratificação (se acordo em plena forma).

18. Na República Federal da Alemanha, é fundamental para o assunto o art. 59 da Constituição, Lei Fundamental de 23 de maio de 1949: $\S 10^{\circ}$ - O Presidente Federal. . conclui em nome da Federação os tratados com Estados estrangeiros..; $\S 2 .^{\circ}-$ Os tratados que regulam as relações políticas da federação ou que versam sobre matérias que dizem

34. O mesmo JeAn Serres, op. cit., p. 306 define protocolo como qualquer documento oficial que consigne, de maneira autêntica e solene, os resultados de uma negociação. Na prática brasileira, tal ato se denomina Ata (por exemplo, a Ata de Foz do Iguaçu, ou Ata das Cataratas de 22 de junho de 1966, entre Brasil e Paraguai) ou ainda, Declaração (Declaração sobre soberania compartilhada, de 3 de junho de 1966, ao final da $4 .^{\text {a }}$ Reunião dos Chanceleres dos Países pertencentes à Bacia do Prata). Na prática internacional, protocolo é sinônimo de tratado (Protocolo de Genebra de 17 de junho de 1925 - "proibição do emprego na guerra de gases asfixiantes, tóxicos ou similares e de meios bacteriológicos de guerra", que no Brasil está promulgado pelo Decreto n. $67.200 / 70$, DOU de 17/IX/1970).

35. Segundo JEAN SERres, são documentos que consignam o resultado das deliberações de conferências ou de organismos internacionais, quando têm por objetivo criarem normas de direito (id., p. 306). No Brasil, tais deliberações se tornam normas internas, através do mecanismo de aprovação do stratados (aprovação pelo Legislativo e posterior promulgação pelo Executivo), a exemplo, as Convenções da Organização Internacional do Trabalho as normas elaboradas na Agência Internacional de Energia Atômica, (salvaguardas) etc. 
respeito à legislação federal, requerem o assentimento ou $o$ concurso das Assembléias legislativas federais competentes, segundo o caso, sob forma de leis federais. Para as convenções de ordem administrativa, as disposições relativas à administração federal aplicar-se-ão por analogia". Em consonância com o art. 87 da Lei Fundamental, os acordos administrativos são sempre assinados pelos representantes da administração técnica e sua competência será determinada em função do poder de administração aplicável ao objeto do acordo: "se o Bund tem, conjuntamente a competência para editar leis e administrar será competente para assinar tal tipo de acordo; se não tem esta dupla competência, serão os Länder competentes ${ }^{36}$. Esclarecendo o assunto, LIBBERECHT afirma que os Verwaltungsabkommen não podem versar senão sobre matérias que são objeto de atos administrativos ou de disposições de caráter regulamentar em direito interno. . e é, pois, o campo de competência das autoridades administrativas que delimita o campo de aplicação de tais acordos ${ }^{37} \mathrm{em}$ forma simplificada.

19. Na Itália, sua Constituição de 27 de dezembro de 1947, no art. 80 dispõe que "as Câmaras autorizam por leis a ratificação dos tratados internacionais que são de natureza política, que prevêm arbitragens ou processos judiciários, ou ainda que comportam mudanças de território, encargos para as finanças ou modificações de leis", e no art. 75, expressamente veda a submissão a referendo popular a revogação ou derrogação de lei que autorize a ratificação de tratados internacionais. Cabe ao Presidente da República ratificar os tratados internacionais, mas "após autorização das Câmaras, quando esta autorização é necessária (art. 87, § 7. ${ }^{\circ}$ ). Assim sendo, os Acordos administrativos na Itália são os acordos assinados nos limites não incluídos no art. 80, na matéria de competência exclusiva do Executivo e ainda, se tiver havido delegação de função legislativa, nos moldes do art. 76 ("o exercício da função legislativa não pode ser delegada ao Governo, senão com a determinação de princípios e critérios de direção, e unicamente por um tempo limitado e para objetivos definidos").

36. E. LibBrecht, op. cit., p. 67. Relembre-se que o Bund (federação) é a unidade resultante da união política e o Land (plural: Länder) a parte (Estado-Membro).

37. E. LibBRECHT, id., p. 67 , nota 88 . 


\section{Acordos Administrativos e as Anteriores Constituições Brasileiras.}

20. No Brasil, já a Constituição do Império de 25 de março de 1824 criava a necessidade de levarem-se os tratados de "aliança ofensiva e defensiva, de subsídio e comércio (art. $\left.102,8^{\circ}\right)$ depois de concluídos, ao conhecimento de Assembléia Geral, quando o interesse e segurança do Estado o permitirem. No mesmo artigo, dispunha-se que "se os tratados concluídos em tempo de paz envolverem cessão ou troca de território do Império, ou de possessões a que o Império tenha direito, não serão ratificados sem terem sido aprovados pela Assembléia Geral". Ainda dentre as principais atribuições do Imperador, como chefe do Poder Executivo, se arrolava a de "declarar a guerra e fazer a paz, participando à assembléia as comunicações que forem compatíveis com os interesses e segurança do estado (art. $102 \S 9 .^{\circ}$ ), bem como as de "conceder ou negar o beneplácito, aos decretos dos concílios e letras apostólicas, e quaisquer outras constituições eclesiásticas, que se não opuserem a Constituição; e precedendo aprovação da Assembléia, se contiverem disposição geral (art. 102 § 14). Expressamente se dispunha que ao Executivo, e não ao Poder Moderador, cabia "prover a tudo que for concernente à segurança interna e externa do estado, na forma da Constituição (art. $102 \S 15$ ). Assim sendo, o Executivo era o juiz de saber quais tratados deveriam ser levados ao conhecimento da Assembléia Geral, que se manifestaria "quando o interesse e segurança do estado o permitirem" ou no caso de concordatas, na condição de "conterem disposições gerais". Comparativamente ao art. 104 ("O Imperador não poderá sair do Império do Brasil sem o consentimento da Assembléia Geral; e, se o fizer, se entenderá que abdicou a coroa") não havia sanção constitucional para o inadimplemento daquelas disposições. Diga-se, ainda, que o Art. $15 \S \S 12$ e 13 dava atribuição à Assembléia Geral de "conceder ou negar a entrada de forças estrangeiras de terra e mar dentro do Império ou dos portos dele" bem como "autorizar o governo para contrair empréstimos", nada esclarecendo sobre a aprovação de tratados. Enfim, a Constituição de 1824 deixava claro ser da competência do chefe do Poder Executivo, art. $102 \S 6 .^{\circ}$ e $7 .^{\circ}$, "nomear embaixadores e demais agentes diplomáticos e comerciais" bem como "dirigir as negociações com as nações estrangeiras"; segundo o art. 124, deveria "em todos os negócios graves e medidas gerais da pública administração, principalmente sobre a declaração de 
guerra, ajustes de paz, negociações com as nações estrangeiras", ser ouvido o Conselho do Estado, órgão que nunca se instalou e que foi formalmente extinto em 1832, pela Lei de 12 de outubro.

21. Na Seção 5. a do Capítulo II do Título vi, "Das Âtribuições do Poder Executivo, quanto às Relações Internacionais do Estado", do clássico Direito Público Brasileiro e Análise da Constituição do Império, José Antonio Pimenta BUENo, MARQUÊS DE SÃo VICENTE, esclarece que a atribuição de celebrar tratados,

"pertenceria pela teoria ao poder legislativo, porquanto é um ato de soberania, uma expressão do voto nacional; e porque tais convenções internacionais se transformam em leis internas do País, que devem ser religiosamente observadas, que produzem direitos e obrigações" ${ }^{38}$. E continua o mesmo autor:

"entretanto, praticamente compreender-se que além dos conhecimentos que são indispensáveis, assim de todos os interesses nacionais, como dos países estrangeiros é de mister que o centro negociador não tenha interrupções em sua vigilância e ação, como tem o poder legislatvo, que esteja sempre esclarecido de todas as informações, que opere muitas vezes em segredo, que aproveite as ocorrências e oportunidades; compreende-se que a celebração de tratados não pode ser cometida senão ao mesmo poder que é encarregado de nomear os agentes diplomáticos, e de dirigir as negociações internacionais; seria dividir a unidade de vistas e de ação, e comprometer os interesses públicos" ${ }^{39}$. Acentua, a seguir, que

"também se manifesta que a dependência para ratificação de prévia aprovação do poder legislativo, quando eles não ultrapassarão as atribuições do Executivo, não seria fundada e pelo contrário enervaria muito a ação deste, basta que prevaleça

38. José Antonio Pimenta Bueno, Direito Público e Análise da Constituição do Império, Brasil, Ministério da Justiça e Negócios Interiores, Serviço de Documentação, Rio de Janeiro, 1958, p. 242.

39. id., ibid. 
essa dependência sobre os assuntos que não cabem em sua alçada" ${ }^{40}$. Diz, em seqüência que:

"pelo que acabamos de indicar já se vê que a faculdade dada ao poder executivo não é arbitrária, sim limitada pelos princípios constitucionais do Estado, que ele jamais deve ultrapassar de suas atribuições, que nada pode ratificar que exceda suas faculdades, nada que contrarie as atribuições dos outros poderes ou as leis do Estado, nada que viole as propriedades ou direitos dos súditos nacionais" ${ }^{41}$. Pimenta Bueno deixa claro que as matérias susceptíveis de aprovação pelo Legislativo, quando versadas em tratados, devem ser aquelas que sejam da alçada do mesmo, portanto, um critério ratione materiae para a remessa do texto ao Legislativo.

Diz o MARQUÊS DE SÃo VICENTE, em relação às atribuições do Executivo, na tarefa de celebrar tratados internacionais:

"as estipulações que contrair não podem pois exceder da órbita do que ele pode dispor, do que está e pende de suas faculdades; quando ultrapas. sem, o poder legislativo está em seu direito de não aprovar ou declarar nulas, embora fique prejudicado todo o tratado. Nem o governo estrangeiro terá direito algum de reclamar, por isso que antes de efetuar a negociação tinha o dever de consultar e saber quais as leis fundamentais do império, ver que elas não davam tais faculdades ao poder executivo, e refletir que a convenção feita com quem não tem poderes é nula, ipso jure, ou feita só ad referendum, e portanto sujeita a essa eventualidade $^{42}$.

Pimenta Bueno deixa explícito que a ocorrência do Legislativo na elaboração de tratados se dá, quando estes visam à modificação da legislação interna:

"semelhantemente, em um tratado de navegação comércio, postal ou outro qualquer, o poder

40. id., ibid.

41. id., ibid.

42. id., ibid. 
executivo não é autorizado a alterar os direitos estabelecidos de importação, exportação, a derrogar nenhuma disposição das leis ou seja administrativas, civis, comerciais, criminais ou de processos, pois que seria exceder suas atribuições e obras sem poderes" ${ }^{43}$.

Sentencia aquele celebrado autor que,

"durante o curso das negociações, e mesmo enquanto o interesse e segurança do Estado não permitir, convém ou pode ser necessário não dar publicidade a tais assuntos; cumpre porém que os ministros não levem a excesso, que não abusem desta faculdade, pois que o poder legislativo tem não só o direito de ser informado, mas de tomar-lhes contas, e mesmo de responsabilizá-los. Não seriam pois admissíveis subterfúgios que tendessem a nulificar esta inspeção e direitos, que tanto interessam à sociedade" ${ }^{44}$.

Pelo que se depreende dos comentários de Pimenta Bueno, só seriam remetidos ao Legislativo, na vigência da Constituição do Império, os acordos que, ratione materiae, versassem sobre assuntos que, se legislados na esfera interna, o seriam por atos normativos para cuja perfeição se exigisse a ação do Executivo e do Legislativo.

22. Nas Constituições Federais republicanas que se seguiram, as atribuições do chefe Executivo no que respeita à conclusão de tratados internacionais, se encontram rigidamente limitadas. Deve o Presidente da República, não mais levar ao conhecimento do Legislativo "quando o interesse e a segurança do Estado o permitirem", os textos dos tratados por ele negociados, mas, à falta de distinção nos textos constitucionais, de quaisquer ajustes, convenções e tratados (expressões que aparecem pela primeira vez no art. 48 da Constituição Federal de 1891, art. $48 \S 15$, sendo a expressão ajustes,

43. id., p. 243

44. Apesar de o Brasil participar de organizações internacionais desde os começos do Século (União Pan-Americana, antecessora da atual Organização dos Estados Americanos, (OEA) ou desde 1919 (Liga das Nações e Organização Internacional do Trabalho), ou ainda das uniões administrativas do final do Século XIX (União Postal Universal, União Internacional das Telecomunicações), as disposições sobre semelhante fenômeno político somente aparecem na Constituição $\mathrm{Fe}$ deral de 1967 , art. $8 .^{\circ}$, I. 
suprimida nas posteriores). Em todas, na instituição das atribuições do Congresso, aparece a expressão "resolver definitivamente sobre tratados e convenções com as nações estrangeiras", como competência exclusiva do Congresso Nacional (a partir de 1967, o texto constitucional inclui a expressão "atos internacionais" ao lado de tratados e convenções). Igualmente, em todas, aparece a competência privativa do Presidente da República de manter relações com os Estados estrangeiros e entabular negociações internacionais; e ainda celebrar ajustes, convenções, tratados internacionais, ad referendum do Congresso Nacional; note-se que, a Constituição de 1934 suprimiu o advérbio sempre de antes de "ad referendum", no que foì seguida pelas demais, inclusive a Constituição Federal vigente.

\section{Acordos Administrativos e a Constituição Vigente.}

23. A Constituição vigente, Emenda n. ${ }^{\circ} 1 / 69$, dispõe competir à União, art. 8. ${ }^{\circ}$, I, "manter relações com Estados estrangeiros e com eles celebrar tratados e convenções; participar de organizações internacionais ${ }^{45}$. No seu art. 44, I, dispõe ser da competência exclusiva do Congresso Nacional, "resolver definitivamente sobre os tratados, convenções e atos internacionais celebrados pelo Presidente da República". Como competência privativa do Presidente da República, o art. 81, $\mathrm{X}$, arrola o de "celebrar tratados, convenções e atos internacionais, "ad referendum" do Congresso Nacional". Em face do texto constitucional, algumas questões se colocam ao intérprete: a) incluem-se no art. $44, \mathrm{I}$ e $81, \mathrm{X}$, os atos unilateriais que criam ou extinguem direitos na comunidade dos Estados, tais como o protesto, denúncia de tratados, reconhecimento de Estados ou de Governos, ou outros de rotina diplomática (recebimento de representantes estrangeiros, acreditamento de cônsules, notas reversais, etc.) ? b) qual a situação de normatividade dos atos votados pelo Brasil nos organismos internacionais, tais como empréstimos em bancos internacionais, resoluções, recomendações e decisões tomadas na oNU, na Organização Internacional do Trabalho e demais organismos especializados da mesma? c) se é prática internacional, à qual

45. Pontes de Miranda, Comentários à Constituição de 1967, com a Emenda $n 0^{\circ} 1$, de 1969, tomo III, (arts. 32-117), 2. ${ }^{a}$ Edição, revista, São Paulo, Edit. Revista dos Tribunais, p. 110 (itálicos do original). 
o Brasil tem aderido, a existência de acordos administrativos, qual sua situação face à legislação brasileira?.

24. Ao comentar o Art. 44, I, Pontes de Miranda afirma que a resolução do Congresso Nacional "é que dá perfeição ou conclusão (e não só eficácia) ao tratado, convenção, ou acordo." ${ }^{46}$ Permito-me fazer um reparo: os tratados, convenções ou acordos internacionais, na técnica da Constituição Federal vigente, entram em vigor, como quaisquer leis, ou seja, por um ato do Executivo, a promulgação e sua publicação. Os decretos-legislativos, que são a manifestação formal do Legislativo, não têm o poder de criar normas eficazes erga-omnes, automaticamente aplicáveis pelos juizes; obrigam tão-somente o Executivo, na relação político-jurídica das fases do processo legislativo. A aprovação legislativa é uma das fases da perfeição dos tratados, convenções ou acordos, que se termina, na esfera interna, com a promulgação e publicação e na esfera internacional, com a troca dos instrumentos de ratificação ou por outro ato qualquer, estipulado entre as Altas Partes Contratantes. o próprio PoNTES DE MIRANDA quem o reconhece, no mesmo texto, ao admitir, que a aprovação legislativa é uma condição suspensiva, verbis "o ato do Presidente da República ou dos seus agentes, é incompleto; falta-lhe integração de fundo e de forma" ${ }^{47}$. Para bem fundamentar sua opinião, escreve PoNTES DE MIRANDA:

"qualquer acordo interestatal, inclusive de participação em organizações supra-estatais ou interestatais, está sujeito à aprovação do Congresso Nacional. Não importa o nome que se dê ao acordo (tratado, convenção, acordo, declaração, protocolo), nem a classificação ou discriminação (tratados políticos, tratados econômicos ou tratados de comércio, tratados consulares), nem, sequer, a distinção de fundo (tratados-contratos, tratados-leis)" 48 .

25. No seu Comentários à Constituição Brasileira, assim se expressa o Professor MANoel GonçAlves FerReira FILH0: "ora, a expressão atos internacionais abrange muito

46. id., ibid., p. 109.

47. id., ibid., p. 115.

48. Manoel Gonģalves Ferreira Filho, Comentários à Constituição Brasileira: Emenda Constitucional n..$^{\circ}$ de 17 de outubro de 1969, São Paulo, 1. ${ }^{\mathrm{a}}$ Ed., $1974,2 .^{\circ}$ v. (arts. 46 a 129), Saraiva, p. 140. 
mais do que tratados e convenções. cem os tratados e convenções inseridos como espécie" ${ }^{49}$. E conjetura aquela autoridade: "dessa forma, interpretado literalmente, decorre do preceito em tela que todo ato que importe em criação de direitos e obrigaçõs para o Brasil na órbita internacional deve ser celebrado pelo Presidente da República e aprovado pelo Congresso Nacional para ser válido em face do direito interno. Isto seria exato quer em relação aos atos unilaterais (reconhecimento, protesto, notificação, renúncia), quer em relação aos acordos internacionais (tratados, convenções) ${ }^{50}$. Com grande descortino, sua Excelência reage a tal interpretação absurda, por ir "além da provável intenção do constituinte. Certamente quis este reagir contra a tendência universal da celebração pelo Executivo de acordos internacionais, sem a forma de tratado e convenção, e assim fugindo ao controle do Legislativo... por isso, a expressão atos internacionais no preceito em tela equivaleria a acordos internacionais, não abrangendo, portanto, os atos unilaterais " 51 . Com maior razão, o mesmo se pode aplicar aos atos da rotina diplomática, por vezes bastante importantes seja como etapas da formação de um verdadeiro tratado (notas reversais durante uma negociação diplomática) seja como autênticos instrumentos de interpretação de tratados ou de legitimação dos agentes do Estado na comunidade internacional, que pela natureza, dispensam a aprovação pelo Congresso Nacional.

26. Quanto à entrada em vigor no Brasil dos atos votados em organismos internacionais, o sistema brasileiro não conhece ato normativo específico, como os "Règlements" do direito francês, que os distinga dos tratados em devida forma ou dos "executive agreements". Podem ser incorporados à legislação brasileira por tratados na devida forma (Acordo Brasil, EUA e Agência Internacional de Energia Atômica, de 1967, emendado em 1972, Decreto n. ${ }^{\circ}$ 71.207/72, "para a aplicação de salvaguardas" nas relações bilaterais Brasil-EUA, sendo que as mesmas contaram com a colaboração do Brasil enquanto membro da AIEA e que são as vigentes no INFCIRC/

49. Manoel Gonçalves Ferreira Filho, id., p. 141 (itálicos não são do original).

50. Manoel Gongalves ferreira Filho, id., bis ibid.

51. Veja-se, do autor, As Salvaguardas nos Acordos Nucleares, Coleção Jurídica JB n. ${ }^{\circ}$ 17, São Paulo, Bushatsky, 1976. 
66/Rev. 2) ${ }^{52}$, ou se constituirem em simples "Executive Agreements" (as listas adotadas nas negociações do GATT, da ALALC, ou aindas as inúmeras resoluções votadas nos demais organismos internacionais).

27. Ora, tanto no caso dos contratos administrativos internacionais, quanto no caso dos "Executive Agreements" propriamente ditos, deve examinar-se o efeito de sua nãosubmissão ao referendo do Congresso Nacional. Mais especificamente, trata-se de saber se os acordos administrativos são válidos no direito brasileiro, questão essa que se pode exprimir de duas outras formas: a) se há necessidade da aprovação legislativa de quaisquer atos internacionais firmados, inclusive por autoridades menores brasileiras, sem as formalidades dos tratados em devida forma, que dispensem a ratificação entre os signatários; b) se os atos normativos internacionais não submetidos ao Congresso Nacional são válidos na esfera da comunidade internacional e no Brasil.

28. O assunto foi versado por dois dos maiores internacionalistas brasileiros, Embaixador HILDEBRANDo ACCIOLY ${ }^{53}$ e o Professor HAROLDO VALLADÃo ${ }^{54}$, em polêmica a respeito da dúvida suscitada pelo então Ministro de Estado das Relações Exteriores, o eminente Embaixador RAUL FERNANDES, a respeito da necessidade de submeter-se ao Congresso $\mathrm{Na}-$ cional o Acordo de Pagamentos entre Brasil e França, de 31 de março de 1950, celebrado, por troca de notas, entre o $\mathrm{Mi}$ nistério das Relações Exteriores e a Embaixada de França no Rio de Janeiro. Na consulta ao Professor ValladÃo, o Ministro de Estado dizia: "por se tratar de um Convênio meramente administrativo, que o Governo pode celebrar por sua própria autoridade, tenho dúvidas sobre a necessidade da sua ratificação legislativa, uma vez que a mencionada ratificação viria criar um precedente em contradição com o acordo celebrado com a Inglaterra, que não se entendeu dependente de

52. Hildebrando Accioly, "A Ratificação e a Promulgação dos Tratados" e "Ainda o Problema da Ratificação dos Tratados, em face da Constituição Federal Brasileira" in Boletim da Sociedade Brasileira de Direito Internacional, respectivamente $n .^{\circ} 7$ (janeiro-junho de 1948) e n. ${ }^{\circ}$ 13-14 (janeiro a dezembro de 1951).

53. Haroldo Valladão, Parecer, "Aprovação de ajustes Internacionais pelo Congresso Nacional" in Boletim da Sociedade Brasileira de Direito Internacional, n. 11-12 (janeiro a dezembro de 1950).

54. citus apud Haroldo Valladão, Parecer, "Aprovação....id., p. 95. 
aprovação do Congresso Nacional" e terminava por pedir brevidade no Parecer, pois não poderia o referido acordo com França "entrar em vigor imediatamente, se a aludida ratificação for indispensável" 55. Com acuidade, pondera HILDEBRANDo ACCIOLY "como se vê, RAUL FERNANDES, grande autoridade na ciência jurídica, punha em dúvida, para o caso em espécie, a necessidade da aprovação do Congresso, e isso por duas razões de peso: a competência privativa do Poder Executivo e a prática em contrário, noutro caso semelhante" ${ }^{56}$.

29. O Professor VAlladão é de opinião que "há de ser, assim, mantida a interpretação clássica que subordina à aprovação do Congresso Nacional todo e qualquer tratado ou convenção, ainda que com a simples denominação de acordo, ajuste, convênio, etc..." ${ }^{57}$ Interpretando a Constituição Federal de 1946 seu Art. 87, vII, (Compete privativamente ao Presidente da República... celebrar tratados e convenções internacionais ad referendum do Congresso Nacional) e Art. 66, I (É da competência exclusiva do Congresso Nacional.. resolver definitivamente sobre os tratados e convenções celebrados com os Estados estrangeiros pelo Presidente da República), bem como comparando tais textos, com outros, das Constituições Federais anteriores a 1946, de outras leis, conclui o Professor VAlladão que, tradicionalmente, desde a Constituição de 1891, sempre houve o entendimento de que "a aprovação do Congresso Nacional era necessária para quaisquer atos bilaterais internacionais" ${ }^{58}$. Ademais de tais argumentos, aventa os seguintes, enumerados conforme a leitura que do mencionado Parecer fez o Embaixador HILDEBRANDo ACCIOLY verbis: "2. JoÃo BARBALHo justificou a cláusula respectiva da Constituição de 1891 como "garantia contra possíveis abusos, contra a má compreensão e comprometimento dos altos interesses nacionais"; $3 .^{\circ}$ ) Os constituintes republicanos brasileiros "quiseram subordinar o Executivo ao Legislativo, em matéria de política exterior"; $4 .^{\circ}$ ) Seguir o princípio geral da competência privativa dos órgãos constitucionais é criar uma distinção que, com a Constituição de 1891, "não ocorreu, quer aos seus autores, quer aos seus intérpretes"; $5 .^{\circ}$ ) Parece difícil ginal).

55. Hildebrando Acciolly, "Ainda o problema...id., p. 21 (itálicos do ori-

56. Parecer "Aprovação...id., p. 99.

57. Parecer "Aprovação...id., p. 97.

58. "Ainda o problema...id., p. 21/22. 
separar as matérias da competência privativa do Poder Executivo das que o são do Poder Legislativo, talvez porque, segundo HAROLDO VALLADÃo, as atribuições deste, as matérias de sua exclusiva competência, constituem "todo o âmbito do Governo Federal"; 6. ${ }^{\circ}$ ) A Constituição norte-americana, não tendo definido a palavra treaties, quis distinguir os tratados, dos ajustes de menor importância, conforme sugeriu ou insinuou ChARLES CHeneY Hyde; $7 .^{\circ}$ ) "A maior ou menor amplitude de poderes do Governo de um país para negociar e assinar atos internacionais" depende dos textos das Constituições e leis desse país e constitui "assunto típico de direito interno, que escapa de todo ao Direito Internacional", porquanto alguns internacionalistas sustentam que o Direito Internacional deixa à competência exclusiva de cada Estado o cuidado de determinar quais os órgãos constitucionais investidos da competência internacional; $8 .^{\circ}$ ) "No Direito das Gentes, o princípio aceito - e pelo Brasil até em convenção, devidamente aprovada e ratificada - o da absoluta necessidade de ratificação para todos os tratados, sem qualquer exceção (o grifo é nosso) ; $9 .^{\circ}$ ) A Convenção de Havana sobre tratados determina a obrigatoriedade da ratificação; $100^{\circ}$ ) Apesar de tudo, é admissível uma exceção à "regra da aprovação pelo Congresso, dos tratados e convençóes": é a referente aos "pactos estipulados pelos chefes militares, nos limites de suas atribuições" ${ }^{59}$.

30. Na sua extensa e bem fundamentada argumentação, o Professor VALLADÃo cita a doutrina (além do mencionado JoÃo BARBAlHo: ARISTIDES Milton e Clovis BeVILACQUA), jurisprudência do Supremo Tribunal Federal (caso de extradição, com prisão preventiva do extraditando: "assente na jurisprudência a regra, já indiretamente prevista no acórdão do STF de 14 de junho de 1905 (O Direito), 98-243, de que só se permitiria a prisão e entrega, havendo tratado e de acordo com este, abolida, por contrária à Constituição Federal, quer a extradição pela simples vontade do Poder Executivo, que a que se fundasse em promessa de reciprocidade, em acordo mediante troca de notas reversais, pois, nos precisos termos dos arts. 34, n. ${ }^{\circ} 12$ e 48 n. ${ }^{\circ} 16$, quaisquer ajustes, convenções ou tratados dependem para resolução definitiva, do Congresso

59. Parecer "Aprovação...id., p. 98. 
Nacional ${ }^{60}$, bem como antigo texto legal que, segundo aquela eminente autoridade, teria criado tradição firme (Lei n. ${ }^{\circ} 23$ de 30 de outubro de 1891 , art. $9 .^{\circ}, \S 3 .^{\circ}$ : Os ajustes, convenções e tratados celebrados pelo Presidente da República, em virtude das atribuições que lhe confere 0 art. $48, n{ }^{\circ} 16$ da Constituição, serão sujeitos à ratificação do Congresso, mediante um projeto de lei formulado pelo Poder Executivo, nos termos do art. 29 da Constituição ${ }^{61}$. A seguir, o Professor VALLADÃo transcreve partes do artigo de HILDEBRANDo Accioly, este, a favor da legalidade dos "Executive Agreements" no sistema brasileiro (que será, a seguir, comentado), para rebater os tópicos, com os argumentos a seguir expostos. Em primeiro lugar, se os tratados que dispensam a aprovação pelo Congresso Nacional são os que independem da ratificação, seria pedir ao Direito Internacional uma resposta a questões de direito constitucional, o que não seria uma orientação aceitável, pois "a maior ou menor amplitude de poderes do Governo de um país para negociar e assinar atos internacionais há de depender, evidentemente, dos textos das constituições e leis desse mesmo país" 62 e prossegue com argumentos de GiUlio Diena, George Scelle, F. Dohousse e José Sette Câmara, no sentido de que o Direito Internacional deve reportar-se ao direito interno dos Estados, para verificar a legitimação dos signatários dos tratados e demais atos, e a necessidade de ratificação dos mesmos pelos Legislativos, com vistas a evitar-se a invalidade deles; enfim, cita a Convenção de Havana de 1928 (lei no Brasil, Decreto n. ${ }^{\circ} 18.956$ de 22 de outubro de 1928) verbis: "Os tratados serão celebrados pelos poderes competentes dos Estados ou pelos seus representantes, segundo o seu direito interno respectivo" e se "Os tratados não são obri-

60. A Lei n. ${ }^{\circ} 23 \% 1891$, que reorganizou os serviços da administração federal, mal diz ao referir-se à ratificação dos tratados pelo Congresso Nacional. A terminologia acertada seria, mesmo então, aprovação. Ratificação diz respeito à repetição de um mesmo ato, entre as mesmas pessoas, e dá idéia de um segundo momento, quando o ato se aperfeiçoa. Ora, o Legislativo não foi quem assinou o ato e as pessoas envolvidas são Estados, cujos órgãos de representação exterior, capazes de criar direitos e obrigações entre Estados, é o Executivo. Se o acordo internacional foi formalizado entre Executivos, é da competência destes, num segundo momento, repetir o mesmo pactuado, pela ocasião da assinatura primeira. O que faz o Legislativo é aprovar, referendar, preencher uma das várias condições para a perfeição do ato internacional, quando tal se exigir. (O texto da citada Lei se encontra no Parecer mencionado do Professor Valladão, p. 97, com a observação dele de que ela se encontrava em vigor, "no que não foi expressamente revogada").

61. H. Valladäo, Parecer...id., p. 102.

62. H. Valladão, Parecer...id., p. 103/104. 
gatórios senão depois de ratificados pelos Estados contratantes, ainda que esta cláusula não conste nos plenos poderes dos negociadores, nem figure no próprio tratado (Arts. $1 .^{\circ}$ e $5^{\circ}$ ). Em segundo lugar, ao argumento de $H$. ACCioly de que, conforme o princípio geral da competência privativa dos órgãos constitucionais, só os tratados que versassem sobre matéria exclusiva do Poder Legislativo é que deveriam depender da aprovação legislativa, o Professor VALLADÃo rebate com a tese de que, desde os comentadores da Constituição de 1891, o mencionado BARBALHo, a aprovação dos tratados pelo Congresso visou ao controle dos atos do Presidente da República, sendo que "não olharam os constituintes republicanos brasileiros a matéria ou a importância dos ajustes internacionais" "Quiseram subordinar o Executivo ao Legislativo em matéria de política exterior, não permitindo assumir o Brasil quaisquer responsabilidades, na ordem internacional, sem o consentimento do Senado" ${ }^{63}$. Enfim, o Professor VAlladão rebate as teses que pretendem ligar a existência dos "Executive Agreements" no Brasil, ao direito de outros povos, em especial ao dos Estados Unidos da América, afirmando que estes, França e Alemanha, "são nações que restringiram, em parte, a competência, ali tradicionalmente incondicionada do Chefe de Estado na matéria. No Brasil, a evolução se fez mais completamente" ${ }^{64}$, no sentido de limitar a competência do Executivo para quaisquer tratados. Admite, contudo, o Professor VALLADÃo, e cita LAFAYETTE, "a única exceção verdadeiramente admissível para a regra da aprovação pelo Congresso dos tratados e convenções diz respeito aos "pactos estipulados pelos chefes militares nos limites de suas atribuições LAFAYETTE, op. cit. II, p. 287) ${ }^{65}$.

31. O Embaixador Hildebrando ACCioly, já em artigo anterior ao mencionado Parecer do Professor HARoldo VAllaDÃo, tivera a oportunidade de expressar seu apoio à tese da validade dos "Executive Agreements" em face da Constituição Federal. Em 1951, contudo, no Boletim da Sociedade Brasileira de Direito Internacional, nos números 13 e 14, janeiro-dezembro, páginas 20, no artigo intitulado "Ainda o problema da Ratificação dos Tratados em face da Constituição Federal Brasileira", busca o eminente internacionalista refutar as opiniões

63. H. Valladão, Parecer...id., p. 106.

64. H. Valladão, Parecer...id., p. 108. A obra de Lafayette referida são os Princípios de Direito Internacional, II, 1902.

65. "Ainda a problema...id., p. 22. 
do outro não menos eminente doutrinador da ciência jurídica brasileira. Começa H. Accioly por afirmar que "os fatos indicam que nunca se entendeu entre nós, que a aprovação do Congresso Nacional era necessária ou, melhor, indispensável "para quaisquer atos bilaterais internacionais ${ }^{66}$ e cita que, na vigência da Constituição de 1891, quando se promulgou o Código das Relações Exteriores, vários acordos constam que não foram remetidos à aprovação do Legislativo: "ajustes bilaterais, com a Alemanha de 10 e 29 de julho de 1899), a Argentina (de 9 de agosto de 1895) a Áustria-Hungria (de 4 de junho e 24 de setembro de 1891), a Bélgica (de 4 e 9 de julho de 1897), a Bolívia (de 10 de maio de 1895 e de 30 de outubro de 1899), o Chile (de 10 de janeiro de 1896), França, Itália, Perú, Portugal, Suíça". "Um dos acordos com Portugal (o de 9 de maio de 1898) dizia respeito a assunto que à primeira vista, deveria talvez passar pelo Congresso Nacional: era a permuta de encomendas postais sem valor declarado ${ }^{67}$ E continua aquele autor "de datas posteriores a 1.900, mas ainda sob a vigência da Constituição de 1891, poderíamos mencionar vários outros exemplos, inclusive alguns acordos para demarcação de fronteiras e outros sobre a troca de correspondência diplomática em malas especiais ${ }^{68}$.

32. Quanto à opinião de BARBALHo, afirma ACCIOLY que ela não impediu a prática, na vigência da Constituição Federal de 1891, dos acordos independentes de aprovação legislativa. Com justeza, H. Accioly afirma custar-lhe crer que "o nosso Poder Executivo, ou melhor, o Presidente da República, não tenha noção dos "altos interesses nacionais" e fosse comprometê-los em matéria atinente à sua competência privativa, ao tratar, por intermédio de seus agentes, com países estrangeiros" 69 .

33. Ao argumento de que os constituintes brasileiros de 1946, diga-se, ademais, todos os constituintes republicanos, inclusive os que elaboraram o texto vigente, quiserem subordinar o Executivo ao Legislativo, em matéria externa, H. ACCioly rebate com a tese que afirma caber no sistema presidencialista a responsabilidade pela orientação e execução da política externa, simplesmente ao Poder Executivo. "A circunstância de ser

66. id., ibidem, bis ibidem.

67. id., ibidem, pg. $22 / 23$.

68. id., ibidem, p. 23 (itálicos do original).

69. id., ibidem, p. 23. 
a nomeação dos chefes de missão diplomática sujeita, à aprovação do Senado não significa, absolutamente, que este deva dirigir a política exterior do País; ao Senado também cabe, por exemplo, a aprovação da nomeação dos Ministros do Supremo Tribunal Federal, sem que isso possa importar na menor interferência de nossa Câmara alta na ação do mais alto órgão judiciário da República ${ }^{70}$.

34. Em seguida, o Embaixador H. Accioly passa a examinar a alegação de que "o princípio aceito é o da absoluta necessidade de ratificação, para todos os tratados, sem qualquer exceção" que inquina ser inexata, especialmente, hoje em dia. Para tanto, invoca o testemunho de inúmeros autores norte-americanos e europeus, brasi'eiros, e da jurisprudência da antiga Corte Permanente de Justiça Internacional, em sentença relativa à jurisdição da Comissão Internacional do Oder, em 1929, quando se admitiu que "as convenções", salvo em certos casos excepcionais, só se tornam obrigatórias em virtude da ratificação ${ }^{71}$. Quanto à prática internacional, H. ACCIOLY menciona opinião de autores consagrados, no sentido de que a ratificação é largamente dispensada, em acordos de pequena importância, e, note-se, em acordos da mais alta relevância, igualmente.

35. Quanto à invocação da Convenção de Havana de 1928, sobre tratados, é de notar-se que no art. $8 .^{\circ}$, há a admissão implícita da dispensa da ratificação dos tratados para sua imediata vigência: nos tratados vigorarão desde a troca ou depósito das ratificações, salvo se, por cláusula expressa, outra data tiver sido convencionada". Ora, como bem notou o autor citado, "e expressão tratados (usada no art. 1.0 da Convenção verbis" os tratados não são obrigatórios senão depois de ratificados pelos Estados Contratantes, ainda que esta cláusula não conste nos plenos poderes dos negociadores, nem figure no próprio tratado") p.oderá ser interpretada como não se aplicando aos acordos em forma simplificada ${ }^{72}$.

36. Enfim, escreve H. ACCioly: "a exceção admitida explicitamente por VALLADÃo já prova, por si só, que sua tese da exigibilidade da aprovação prévia do Congresso $\mathrm{Na}$ cional para todos os acordos internacionais não é tão absoluta

70. citus apud H. Accioly, "Ainda...id., p. 26.

71. H. Accroly "Ainda...id., p. 31.

72. id., ibidem, bis ibidem. 
como ele pretendeu. A admitir-se, porém, uma exceção não prevista na Constituição, não há motivo para que se possam aceitar outras' ${ }^{73}$. As razões jurídicas que, à vista do texto constitucional, justificariam a prática dos acordos sem aprovação do Legislativo, ainda segundo ACCioLY, devem ser encontradas "na competência privativa do Poder Executivo, embora em casos de urgência e à vista do costume internacional, talvez se possa invocar a força maior. A tese da competência privativa é perfeitamente razoável. Se a matéria de um acordo é das que cabem peculiarmente dentro das atribuições constitucionais do Poder Executivo, e dado que a este é que compete o exercício das relações com outros Governos, não há por que se lhe deva negar a autoridade para celebrar o dito acordo e pồ-lo em vigor, sem intervenção do Poder Legislativo. (É curioso assinalar, de passagem, que o mesmo critério como que constitui tradição, entre nós, pois já era seguido ao tempo do regime imperial. Posta de parte a Carta de 1824, parecenos digno de menção, por exemplo, o seguinte trecho da Fala do Trono, na abertura da Assembléia Geral em 3 de maio de 1855, relativamente a uma convenção com Portugal, destinada a "reprimir e punir o crime de falsificação de moeda e papéis de crédito": "Esta convenção ser-vos-á presente para obter a vossa aprovação na parte em que depende de Ato Legislativo ${ }^{74 "}$.

37 No apoio de suas afirmações, H. Accioly cita QUINCY WRIGHT, PAUL DE VISSCHER e JAMES O. MURDoCK, o qual, mais precisamente afirma: "O Presidente tem o direito de fazer acordos executivos, se a matéria cabe dentro de sua autoridade sob a Constituição; em outras palavras: se se trata de matérias que estão claramente dentro de sua competência, como Chefe Executivo ou Comandante-Chefe ${ }^{75}$.

38. Para terminar seu alentado artigo, H. Accioly apresenta um fato ocorrido em 1952, no Senado Federal brasileiro, verbis: "Discutia-se ali um Acordo entre Brasil e a Itália, firmado a 5 de julho de 1950, "sobre investimentos", o qual continha uma cláusula na qual se declarava que certas transferências, mencionadas naquele ato bilateral, seriam "efetuadas de comum acordo, por via da conta prevista no Ajuste de Pagamentos concluído entre o Banco do Brasil e o Uffizio Italiano dei Cambi" O Acordo foi submetido ao Congresso

73. id., ibidem, bis ibidem.

74. id., ibidem, p. 32.

75. id., ibidem, p. 33 . 
Nacional, mas não o Ajuste de Pagamentos. Em parecer da Comissão de Constituição e Justiça do Senado, de que foi relator o Senador ATTILIO VIVACQUA, parecer subscrito por toda Comissão, declarou-se o seguinte: "O aludido Ajuste de Pagamentos. ., ao qual se reporta o Acordo em estudo, não contém matéria da competência do Poder Legislativo... fica, portanto desfeita a dúvida suscitada em torno da validade do referido Ajuste de Pagamentos (Diário do Congresso Nacional de 22 de maio de 1952 , p. 3.092) ${ }^{76}$. Em conclusão, $H$. AcCIOLY reitera: "seja como for, o que principalmente desejávamos era esclarecer que, entre nós, o costume já de muitos anos - ainda que se pretenda estabelecido extra-legem - é o de não se exigir a aprovação do Congresso Nacional para certos atos internacionais, e mostrar que, nisto, acompanhamos a corrente moderna e a melhor doutrina ${ }^{77}$

39. Na praxe oficial brasileira, verificou-se, em levantamento efetuado a partir da Coleção de Atos Internacionais, publicação oficial do Ministério das Relações Exteriores, (Divisão de Atos Internacionais), que não publica todos os atos internacionais subscritos pelo Brasil, mas só os mais importantes, que até o número 833 (Acordo Brasil, Costa-Rica, em devida forma, DO 12 de março de 1976) e até 11 de outubro de 1976, data do exame dos dados, dos 833 tratados assinados, 475 são em devida forma, ou seja, aprovados por Decreto-Lei legislativo, contra 258 sem aprovação, portanto acordos administrativos, ou seja, $65 \%$ em devida forma, contra $35 \%$ em forma simplificada. No levantamento, tomou-se a precaução de não contar e de excluir os acordos assinados e publicados nos períodos que, desde 1930, o Congresso Nacional esteve fechado: de 11/XI/1930, Decreto 19.398, que dissolveu o Congresso Nacional, passando o Governo Provisório a exercer discricionariamente, em toda sua plenitude, as funções do Poder Executivo e do Poder-Legislativo, até 15/XI/1933, data da instalação da Assembléia Constituinte Nacional; de 10/XI/1937, golpe de Getulio Vargas, até 2/2/1946, instalação da Assembléia Constituinte eleita em 2/12/1954"; e de 13/XII/1968, Ato Complementar n. ${ }^{\circ} 38$ (que determinou o recesso) até $30 / \mathrm{X} / 1969$, data em que entrou em vigor a

76. id., ibidem, bis ibidem.

77. Afonso Arinos de Melo Franco, Poder Legislativo e Política Internacional in Estudos de Direito. Constitucional, Rio de Janeiro, Ed. Revista Forense, 1957 , p. 265. 
Emenda n. ${ }^{\circ}$ 1/69. Dos 258 "Executive Agreements", 214 são trocas de notas, seja entre o Ministério das Relações Exteriores do Brasil e uma Embaixada estrangeira, seja de nossa representação diplomática no exterior, com os Ministérios dos Negócios Estrangeiros do país acreditante, meramente assinadas e trocadas, com posterior publicação no Diário Oficial da União; 22 são tratados articulados, com preâmbulos, de vigência imediata, assinados pelo Ministro de Estado das Relações Exteriores e pelo chefe da missão diplomática de outro país, meramente publicados no Diário Oficial da União. Outros 22 tratados foram passados no recesso parlamentar de 13/XII/1968 a 30/X/1969, aprovados por Decretos-Leis, e promulgados por Decretos, constituindo-se em autêntica aberração jurídica, pois são atos que entraram em princípio na vigência dos atos normativos, em três momentos: na publicação do decreto-lei (que tem efeito de lei, imediato); na promulgação, e na aprovação, a posteriori, pelo Congresso Nacional.

40. Dos "Executive Agreements" vigentes, alguns versam sobre matéria tipicamente da alçada da política exterior, reservada ao Poder Executivo: para suspensão de vistos em passaportes especiais e diplomáticos, para troca de correspondência diplomática em malas especiais, compromisso para submeter-se questão a arbitramento, interpretativos de tratados em devida forma, constituição de comissões mistas para executarem determinações de outros tratados, etc. Outros, matérias que se acham reguladas, em entendimentos com outros países, por acordos em devida forma: acordos sobre serviço militar, para aproveitamento de recursos minerais do Brasil ou de país diferente, convênios de comércio, culturais, concessão de privilégios alfandegários recíprocos, radioamadorismo, venda de trigo, recuperação e conservação de pontes internacionais, interconexão rodoviária e ferroviária, pesca de camarão etc.. Dentre os últimos, há vários que versam sobre assuntos que, se fossem tratados na esfera interna, seriam da competência conjunta do Executivo-Legislativo (note-se que se disse conjunta e não subordinada, pois seria demonstrar total desconhecimento da organização constitucional brasileira e do processo legislativo, pretender que um dos Poderes da República estaria subordinado ao outro). Quanto às denominações dos atos, refletem a mesma confusão existente no que se refere aos acordos em devida forma: ora são ajustes, ora convênios, ora acordios administrativos, ora protocolos, mas, em nenhum, aparece a denominação tratado. 
41. Fazendo a exegese do texto da Constituição Federal de 1946, Afonso ARINo DE Melo Franco cita BASDEVANT e afirma que "foi exatamente esta distinção entre convenções e tratados, que o jurista francês declara ser repelida pelos autores, que o legislador brasileiro, mal avisado, introduziu no texto da nossa Constituição ${ }^{78}$. Neste caso, segundo o mesmo autor, o erro de técnica legislativa, levaria o Executivo à possibilidade de não rotular os atos internacionais de tratados ou convenções, para eximir-se da obrigação do envio ao Congresso Nacional. Contudo, nem a inclusão no texto constitucional vigente da expresão "atos internacionais", não tem impedido a adoção de "Executive Agreements" no Brasil.

42. Ora, existe a praxe no Direito Constitucional Brasileiro de não remeter todos os atos internacionais à apreciação do Congresso Nacional para seu referendo. Para evitar - fato "de que no Brasil a prática resulta em admitir, por costume extra legem, exceções ao princípio da obrigatoriedade do referendum legislativo ${ }^{79}$, o Embaixador G. E. Do NASCIMENTo E SILVA propõe que se adote como texto constitucional no Brasil, a enumeração dos assuntos que, se versados em atos internacionais, devam ser remetidos ao referendo do Legislativo, à semelhança da Constituição de França de 1958 que estipula, verbis, em tradução de Sua Excelência: "os tratados de paz, os tratados comerciais, os tratados ou acordos relativos à organização internacional, os que afetam as finanças do Estado, os que modifiquem disposições de natureza legislativa, os relativos ao estado das pessoas, os que impliquem em cessão, permuta ou anexação de território não poderão ser ratificados ou aprovados a não ser em virtude de uma lei ${ }^{80}$.

43. Parece ser opinião acertada, a da enumeração dos assuntos de aprovação obrigatória do Congresso Nacional, quando insertos em contexto normativo internacional. A mera colocação das palavras "atos internacionais" no texto constitucional, ao lado de tratados e convenções aprováveis pelo referendo do Congresso Nacional, pode ser interpretada de maneira absurda, de tal forma que se obrigue o Executivo a

78. Geraldo Eulálio do Nascimento e Silva, Direito Internacional no Projeto da Reforma da Constituição in Boletim da Sociedade Brasileira de Direito Internacional, n. ${ }^{\circ} 43$ e 44 (janeiro-dezembro de 1966), p. 14.

79. id., ibidem, bis ibidem.

80. Vide, Brasil, Ministério das Relações Exteriores, Curso sobre Assuntos de Energia Nuclear, p. 306, Rio de Janeiro, Mimeo. 
enviar ao Congresso Nacional, desde uma troca de notas em que o Ministro de Estado das Relações Exteriores propõe um início de negociação diplomática, ela mesma, forma sigilosa de contatos internacionais, ou ainda, notas reversais da rotina diplomática, até mesmo acordos menores, que se inserem dentro do quadro normativo de outros acordos, estes, de natureza propositalmente genérica e imprecisa.

44. Exemplo significativo a provar a necessidade e utilidade dos acordos administrativos é dado pelas relações BrasilRepública Federal da Alemanha, no campo da utilização pacífica da energia nuclear. Evidentemente que existe enorme complexidade na instalação no Brasil, em cooperação germano-ocidental, de uma indústria nuclear, que compreende desde a extração de minérios, até a reciclagem dos combustíveis irradiados (obtenção do plutônio, combustível dos reatores "breeders"), passando por usinas de preparação do combustível em barras, de fábricas de reatores, e problemas correlatos de responsabilidades recíprocas, de financiamentos, etc., e mais as intrincadas questões das salvaguardas e proteção física das instalações nucleares comuns, sob a égide da Agência Internacional de Energia Atômica, complexidades essas que não podem ser compreendidas em um tratado de apenas 11 artigos, como o que foi assinado entre ambos os países, em Bonn, a 27 de junho de 1975, "Acordo sobre Cooperação no Campo dos Usos Pacíficos da Energia Nuclear, tratado em devida forma, tanto que aprovado pelo Decreto Legislativo $n .{ }^{\circ} 85$ de 20 de outubro de 1975 e promulgado pelo Decreto $n .^{\circ} 76.695$ de $1 .^{\circ}$ de dezembro de 1975 (D.O.U. de 2 de dezembro de 1975). Este tratado foi assinado pelo Ministro de Estado das Relações Exteriores do Brasil e pelo Chanceler da República Federal da Alemanha, portanto, os órgãos dos Poderes Executivos que mais propriamente tem capacidade de contrair direitos e obrigações entre ambos os Países (em que pese não ter havido no texto do Acordo nenhuma referência à troca ou exibição de plenos poderes; mesmo pressupondo sua inexistência, o Acordo foi assinado durante visita oficial do Ministro brasileiro a Bonn, o que pressupõe negociações prévias, tanto do texto do Acordo, quanto da conveniência da visita oficial, que, afinal, nada mais é do que a aceitação de um convite oficial do Governo do outro País). Ora, no dia seguinte, 28 de junho de 1975, o Ministro do Estado das Minas e Energia do Brasil, assinaria com o Ministro da Tecnologia da Alemanha Federal um "Protocolo para a Implementação do Acordo sobre Cooperação no Campo dos Usos Pacíficos da Energia Nuclear", 
igualmente em Bonn, uma vez que aquela autoridade brasileira integrava a comitiva na visita oficial. No dia das assinaturas, no Brasil, o Vice-Líder do Governo no Senado, leria e explicaria ambos os Acordos na Câmara Alta, o mesmo tendo sido verificado em relação à Câmara dos Deputados. Eis que, no entanto, em data posterior, unicamente o Acordo assinado entre o Ministro das Relações Exteriores do Brasil e o Chanceler alemão-ocidental seria remetido ao Congrsso Naciona] para seu referendo; o Protocolo não o foi, e nem por isso, os Membros do Congresso Nacional, naturalmente os interessados nas garantias das próprias atribuições constitucionais, reclamariam de semelhante omissão. Tal circunstância faz pressupor que o Congresso Nacional entende que o Protocolo, prendendo-se ao Acordo sobre Cooperação no Campo dos Usos Pacíficos da Energia Nuclear, tanto na sua vigência, quanto na sua interpretação, dispensaria o referendo do legislativo, uma vez que o ato normativo de base, teria já sido por ele referendado. Outros exemplos significativos são, ainda no mesmo campo, dos "Executive Agreements": "Acordo para a Aprovação de um Convênio Especial entre a Comissão Nacional de Energia Nuclear (CNEN) e o Centro de Pesquisas Nucleares de Jülich, Ltda, de 23 de abril de 1971, por troca de notas em Brasília (DO de $10^{\circ}$ de junho de 1971) e o "Acordo para a Aprovação de um Adendo" ao mesmo, de 3 de outubro de 1973 (DO de 27 de novembro de 1973); estes últimos, nada mais são do que decorrência da implementação do "Acordo Geral de Cooperação nos Setores de Pesquisa Científica e de Desenvolvimento Tecnológico" de 9 de junho de 1969, anteriormente aprovado pelo Decreto-Lei n. $^{\circ} 681$ de 15 de julho de 1969 (e promulgado pelo Decreto n. ${ }^{\circ} 65.160$ de 15 de setembro de 1969 (DO de 17 de setembro de 1969). O acordo administrativo para aprovação do convênio CNEN (autarquia federal) e o Centro de Jülich Ltda (órgão não Governamental) não foi remetido ao Congresso Nacional, mas consta de seus Anais, em virtude de discurso de um Senador, que pareceu um tanto decepcionado pela não consulta formal ao Legislativo (Diário do Congresso Nacional, de 16 de junho de 1971, Seção II, p. $2298 / 2307)^{81}$.

81. Tais acordos internacionais, de termos genéricos, que traçam as gran. des linhas de política em comum nas relações bi ou multilaterais e que depen. dem de outros atos internacionais para sua implementação e execução, denomi. nam-se, no jargão diplomático, traités-cadres (tratados-molduras) ou acordos de referência; vide além. 
45. Do exame dos fatos pode-se inferir que já existe estabelecido o entendimento implícito entre Executivo e Legislativo de que os acordos de implementação de outros mais gerais, podem ser acordos administrativos, se aqueles mais gerais, que traçam uma moldura normativa, tiverem sido anteriormente aprovados pelo Legislativo. É o que se pode depreender do comportamento do Congresso Nacional, que silenciou, no caso do Acordo CNEN, Jülich e no caso do Protocolo nuclear Brasil-Alemanha Federal, e ainda, diga-se mais, no caso do Acordo Nuclear Brasil-Israel, de 1966" com entrada em vigor na data da assinatura, em virtude de ser Acordo Complementar ao Acordo Básico de Cooperação Técnica Brasil-Israel" ${ }^{81}$, este, promulgado pelo Decreto n. ${ }^{\circ} 54.247$ de 2 de setembro de 1964 (DO de 8 de setembro de 1964), após o referendo do Congresso Nacional (Decreto-Legislativo n. ${ }^{0} 4$ de 1964).

46. Ao lado das razões apontadas por H. Accioly para justificar, juridicamente, os acordos administrativos, urgência, força maior, competência privativa do Executivo e, sobretudo, o costume internacional, o Embaixador G.E. Do NASCIMENTo E Silva acrescenta outras, não menos despiciendas: "no presente momento, o problema que se nos depara não é o de saber qual a verdadeira interpretação a ser dada ao texto constitucional, mas sim determinar qual a orientação que melhor atenderá aos supremos interesses do Brasil. Em tal sentido, parece-me inegável que a tendência do direito constitucional moderno é o de atenuar o rigor da regra que manda submeter ao parlamento todos os tratados para a devida aprovação. Antes de mais nada, tal prática onera excessivamente o próprio Legislativo que, na maioria dos casos, não possui o pessoal técnico habilitado para apreciar devidamente todos os tratados que lhe são submetidos, daí surgindo um enorme "backlog" de tratados à espera de aprovação. Em segundo lugar, a lógica indica que apenas os tratados de real importância devem ser submetidos ao parlamento, não se justificando a remessa de atos de somenos importância e que versem sobre assuntos de competência exclusiva do Executivo" ${ }^{83}$. Finalmente, observa Sua Excelência que "cumpre encarar a questão objetivamente e lembrar que, em virtude de centenas de trocas de notas, o

82. G. E. Do Nascimento E Silva, Direito Internacional...id., p. 13/14.

83. G. E. Do NASCimento E Silva, Direito Internacional...id., p. 14/15 (os itálicos não são do original). 
Brasil e os Estados estrangeiros criam obrigações mútuas e que tais notas nunca são, nem podem ser enviadas ao Congresso Nacional para aprovação" 84 .

47. Dito isto, é fácil conciliar o texto constitucional com a prática internacional. Desprezando a "mens legislatoris" e atendo-se a uma interpretação sistemática e histórica dos arts. 44, I e 81, X da vigente Constituição Federal (Emenda n. ${ }^{\circ} 1 / 69$ ), depreende-se que as expressões tratados, convenções e atos internacionais são sinônimos e sua constância no texto pode ser tida como um fito de não distinguir a nomenclatura dos atos normativos assinados pelo Brasil com outras pessoas jurídicas de Direito Internacional Público, interpretação que, aliás, não conflita com a existência na Constituição Federal de 1891 das expressões: ajustes e tratados internacionais.

48. A "mens legis" é no sentido de desprezar a diferença de nomenclatura dos atos internacionais e fazê-los susceptíveis de aprovação pelo Congresso Nacional, evitando-se o perigo apontado por Afonso ARINos de Melo Franco.

49. Quanto à distinção entre poderes do Executivo exclusivos e concorrentes com o Congresso Nacional, que determinaria a não-submissão ao Congresso Nacional dos atos que versassem sobre os últimos, não parece adequada, pois a competência exclusiva do Presidente da República de manter relações diplomáticas com Estados estrangeiros pode compreender muito mais do que o simples envio de missões diplomáticas. Pelo contrário, o cerne das relações diplomáticas é a busca de normas de conduta em comum, sejam elas de caráter ético, sejam jurídicas. Nas primeiras se compreendem a boa fé, as relações de amizade e cordialidade, que se expressam com o simples reconhecimento do Estado e envio de missões diplomáticas permanentes. Já nas segundas, podem ser elas soleníssima, do gênero tratados em devida forma, ou simples troca de notas diplomáticas, mas que expressam uma norma nascida do comum acordo entre os Estados. Muito difícil distinguir nestas últimas, onde se encontram as normas que seriam de competência conjunta Executivo-Legislativo, daquelas que são da competência exclusiva do Executivo, mesmo porque, este é o único órgão do Estado aparelhado a manter relações diplomáticas com outros Estados. $\mathrm{Na}$ falta de enumeração dos

84. O texto remete ao seguinte rodapé: "é de recordar que não é estranha ao nosso D. Constitucional a existência de costume (Oliveira Vianna - Instituicões Políticas Brasileiras, Livraria José Olympio Editora, Rio, v. I, 1949, p. 14). 
assuntos que, se versados em tratados, deveriam ser remetidos ao referendo do Congresso Nacional, cabe ao Executivo, por sinal o Poder de maior iniciativa como "policy maker", inclusive na esfera das relações internacionais, determinar quais os atos que deverão ser referendados pelo Congresso Nacional. Tal interpretação não contradiz a história do direito brasileiro e se coaduna com a realidade, tal qual os Estados a vivem na atualidade.

50. Em abalizada monografia, o Prof. CELSO D. DE AlBUQUERQUe MELo é também partidário da validade dos acordos administrativos no Brasil, e desenvolve interessante raciocínio: "pode-se inclusive afirmar a existência de uma norma costumeira ${ }^{84}$ admitindo os acordos do executivo, caso contrário chegaríamos ao absurdo de afirmarmos que as nossas constituições teriam sido violadas todos os anos. E de repetir a Quadri que observa "que por Constituição não é necessário compreender apenas a escrita. A idéia de Constituição se refere a um critério de efetividade, que equivale a praxe constitucional ${ }^{84-\mathrm{B}}$.

\section{Poder Regulamentar no Direito Internacional.}

51. Admitida a legalidade dos acordos administrativos, em especial daqueles que tornam exeqüíveis os tratados mais gerais (esses, referendados, em princípio, pelo Legislativo), pode-se vislumbrar a existência de um verdadeiro poder regulamentar no Direito Internacional ${ }^{85}$. Com efeito, os acordos em devida forma, suficientemente genéricos, são denominados no jargão diplomático, traités-cadre ou acordos de referência, em geral, "regulamentados" por acordos administrativos, como já se fez menção (relações nucleares Brasil-Alemanha-Federal). A gênese da expressão traité-cadre diz bem do exercício pelo Executivo de sua função regulamentar, na esfera da política internacional.

52. "Traité-cadre" é denominação para os tratados genéricos, forjada a partir da expressão do Direito Constitu-

84-B. Celso D. De Albuquerque Melo, Os Tratados na Constituição apud Paulo Bonavides et alii As Tendências Atuais do Direito Público, Estudos em Homenagem ao Professor Afonso Arinos de Melo Franco, Rio de Janeiro, Forense, 1976 , p. $155 / 6$.

85. O "insight" sobre este tema foi ao autor sugerido pela Professora Dra. Odete Madauar, do Departamento de Direito Constitucional e de Teoria do Estado da Faculdade de Direito da USP a quem o autor consigna seus agradecimentos mais cordiais. 
cional francês "loi-cadre". Anteriormente, em França "na IV República, a Constituição de 1946, no seu Art. 13, expressamente proibia a delegação de poderes da Assembléia ao Executivo, no sentido de bem deixar clara a necessária colaboração do Parlamento na feitura da lei; contudo, talvez por ser a delegação de poderes tão inerente ao parlamentarismo e tão arraigada na vida política francesa" ${ }^{86}$, "passou-se a votar leis suficientemente vagas, que o Executivo regulamentaria, e que importavam, na prática, em autênticas delegações" 87. Assim criada a "moldura legislativa" ("loi-cadre"), estava o Executivo autorizado a legislar por decretos (na realidade autênticos decretos-leis) na sua tarefa de poder regulamentar, e se conseguia contornar as disposições do mencionado Art. 13 de que "le Parlement fait la loi seul", cristalina proibição dos decretos-leis ("ordonances") por delegação expressa. Consideradas como uma das fórmulas "un peu hypocrites qui ne ménagent que la forme, aux errements anciens" ${ }^{88}$, ao lado da extensão do poder regulamentar para as matérias que, tradicionalmente seriam da esfera do Legislativo, as "lois-cadre" eram "leis de princípio, que enumeravam, como denominação dos seus capítulos ${ }^{89}$, alguns objetivos a serem atingidos ou algumas reformas a se realizarem, mas, que encarregavam 0 Governo da realidade da tarefa legislativa" ${ }^{90}$.

53. $\quad$ bem verdade que "não existe nenhuma fronteira precisa entre o domínio da lei e o domínio do regulamento, e o trabalho dos mais eminentes juristas não chegou a distinguir um do outro" ${ }^{91}$. Por outro lado, à medida em que as funções governamentais se expandem além dos limites do modelo do "État-gendarme", o princípio liberal dos limites

86. A vigente Constituição francesa de 1958 (V República), no seu Art. 38 (1), voltou a permitir a delegação de poderes do Parlamento ao Chefe do Governo: "Para execução do seu programa, o Governo pode solicitar ao Parlamento autorização para, mediante decretos-leis ("ordonances") e durante um prazo limitado, tomar medidas que pertencem, normalmente, ao domínio da lei".

87. O autor, $O$ Acordo de Cooperação Nuclear Brasil-Alemanha Federal, in Revista Forense n. 253 (no prelo).

88. EmIle BLAMONT, Techniques Parlementaires in Politique et Technique, id., p. 127.

89. A expressão, em francês, é "comme des têtes de chapitre", que seria traduzível por cabeçalho ou ementa. Esta, por ser demasiadamente sucinta e aquele, por não ser integrante da norma jurídica, foram evitados. Preferiu-se "denominação dos seus capítulos".

90. E. Blamont, id., p. 128 .

91. E. Blamont, id., ibid. 
legislativos à ação do Executivo, por excelência o "policy maker", o poder atento às modificaçôes sociais, cada vez mais rápidas, tende a restringir-se. $\mathrm{Na}$ opinião do Professor MARCEL MERLe, "parece que a pressão da técnica deve exercer-se no sentido de uma racionalização do trabalho político, à imagem daquela que se impôs, progressivamente, no mundo dos negócios: de um lado, a lei da divisão do trabalho deveria impor uma rigorosa repartição de tarefas, fundada na especialização das competências; de outro, mecanismos de coordenação deveriam aparecer como o contrapeso necessário à divisão do trabalho" 92. Ainda segundo o mesmo, as estruturas parlamentares parecem oferecer uma resistência feroz à influência da técnica, enquanto que as estruturas do Governo, a ela se adaptam com maior facilidade. Tais fenômenos, necessariamente, trouxeram modificações fundamentais na teoria clássica das relações entre os Poderes do Estado, e, em conseqüência, na teoria vacilante sobre os limites do poder regulamentar do Executivo; sendo assim, as funções do Governo na condução dos negócios externos, especialmente na feitura de atos normativos internacionais, deveriam sofrer influência decisiva, em comparação com o modelo liberal das relações exteriores.

54. No caso dos tratados em devida forma, seja daqueles que instituem organismos internacionais ou sociedades estatais internacionais, seja daqueles que estabelecem mecanismos de consultas entre os Estados (comissões mistas por exemplo), seja ainda daqueles que criam obrigações de transferência de tecnologia ou de recursos entre Estados, é permitido, à maneira de HANS KELSEN, falar-se em um autêntico sistema normativo. No ápice, a normal fundamental, o tratado genérico; logo abaixo, e retirando sua eficácia daquele, acordos administrativos entre órgãos técnicos dos Governos de escalão superior, e na base, contratos entre particulares ou entidades controladas pelo Governo, de caráter eminentemente técnico e cuja vigência dependem do sistema interestatal. Entre estes e os tratados, que criam a norma fundamental, há um intervalo, a ser preenchido exatamente por normas que tornam exeqüivel o texto "constitucional", ele mesmo vago, mera moldura legislativa. Em cumprimento a semelhante tarefa é que aparece - Poder Executivo, na função de regulamentar, na esfera internacional, e no uso de suas atribuições de conduzir as rela-

92. M. Merle, Influence de la Technique...id., p. 38. 
ções externas do País, como um todo, o tratado de referência, pouco importando que o Estado seja uma estrutura de separação tripartida de Poderes, seja uma estrutura de Governo por colegiado, com um Legislativo de fachada ou mesmo sem ele (regimes socialistas).

55. Nos seus comentários à Constituição Federal vigente (Emenda n. $.^{\circ} 1 / 69$ ), Art. 81, III ("compete privatimamente ao Presidente da República... sancionar, promulgar e fazer publicar as leis, expedir decretos e regulamentos para a sua fiel execução) PONTES DE MiRANDA sentencia que "o regulamento não é mais do que auxiliar das leis, auxiliar que só pretender, não raro, o lugar delas, mas sem que possa, com tal desenvoltura, justificar-se, e lograr que o elevem à categoria de lei" 93 demonstrando uma posição demasiadamente rígida e formalística, reflexo de um espírito formado ao tempo das realidades do "Etat-gendarme".

56. No importante artigo A Autonomia do Poder Regulamentar na Constituição Francesa de 1958 (Revista de Direito Administrativo, Rio de Janeiro, v. 84, 1966, p. 24 ss.) o Professor Manoel Gonçalves Ferreira Filho, distingue no sistema constitucional francês vigente, que adota a sistemática de enumerar as matérias do domínio da lei, deixando ao domínio do regulamento as remanescentes, "três tipos de regulamentos, se encararmos sua relação com a lei: o regulamento de execução o regulamento de complementação e o regulamento autônomo" 94. E prossegue aquela autoridade, verbis:"

0 primeiro não foge à linha clássica. Destina-se a facilitar ou a propiciar a execução das leis. Cabe nas matérias reservadas pelo constituinte à lei, mas somente pode explicar o que nesta seja determinado, sem criar obrigação nova (no fundo). Conserva esse regulamento, pois, caráter totalmente subordinado.

O segundo visa a editar regras que decorram dos princípios adotados pelo legislador nas matérias em que lhe cabe apenas traçar as linhas fundamentais. Esse regulamento se subordina aos

93. Comentários.. t. III, p. 314.

94. Manoel Gonçalves Ferreira Filho, A Autonomia do Poder Regulamentar na Constituição Francesa de 1958 in Revista de Direito Administrativo, Rio de Janeiro, 1966, v. 84, p. 35 . 
princípios contidos na lei, mas evidentemente não apenas explicita regras. Substancialmente cria regras dentro de certas linhas afixadas pela lei. Essa forma de regulamento se acha numa zona cinzenta entre a velha e a nova concepção.

0 terceiro é propriamente a novidade. $\mathrm{o}$ regulamento autônomo, legalmente incondicionado, expressão do que VEDEL chamou de "poder normativo governamental" 95. Por ele o governo edita regras somente subordinadas à Constituição. Em seu campo, que é o geral, pode mesmo alterar ou revogar leis anteriores ${ }^{96}$.

Conclui, enfim, que "a imperiosa urgência na adoção de regras e indispensável necessidade de coordenação entre as normas individuais que tornam conveniente estabeleça o mesmo órgão aquelas e estas.. impelem o executivo, o governo, a reclamar um poder normativo inicial e, na verdade, a força das coisas lhe tem dado, sob disfarces ou abertamente, em quase toda parte" ${ }^{97}$. Hoje, no Brasil, é inegável a existência no Executivo de um poder normativo original, em especial, na esfera internacional.

57 Transpostos tais conceitos para o Direito Internacional, e assimilando a lei ao tratado em devida forma (participação do Legislativo na sua perfeição), resulta evidente a existência de um poder regulamentar de execução, de complementação e autônomo, expressos na forma de acordos administrativos ou de atos bi ou multilaterais que dispensam aprovação parlamentar. As resoluções de comissões mistas criadas por tratados em devida forma, (ou mesmo por acordos administrativos), os laudos arbitrais expedidos por tribunais arbitrais internacionais criados em compromisso firmado em tratados, as resoluções de órgãos de sociedades comerciais interestatais criadas por tratados (Itaipu, a exemplo), as notas reversais de concessão de asilo diplomático ou territorial criado por tratados, nada mais são do que o exercício de um poder regulamentar de execução. As notas reversais de interpretação de tratados, as resoluções tomadas nos organismos internacionais, as declarações de reservas no ato de aderir a

95. A nota remete o leitor para Droit Administratif II, $1^{\circ}, 1959$, p. 631.

96. id., ibid., p. 35 .

97. id., ibid. p. 38 . 
tratados já em vigor, são outros exemplos de um poder regulamentar de complementação. O poder regulamentar autônomo seria expresso pela faculdade de o Executivo subscrever acordos administrativos, (os "sole Executive Agreements" do direito norte-americano, ou o que o "Restatement (Second) Foreign Relations denomina "Executive Agreements pursuant to President's Constitutional Authority" no § 144) e de executar atos do exercício do poder de representação externa. Estes últimos são os mais freqüentes e constituem a maioria dos atos da rotina diplomática, revelando a particularidade da função privativa do chefe do Executivo de "manter relações com os Estados estrangeiros (art. 81, IX da Emenda n. ${ }^{\circ} 1 / 69$ ), definitivamente não vinculado a qualquer texto normativo elaborado pelo Congresso Nacional: reconhecimento de Estados ou Governos estrangeiros credenciamento de agentes estrangeiros ou seus, no exterior (salvo os chefes de Missões diplomáticas permanentes que necessitam da aprovação do Senado), troca de notas reversais interlocutórias ou de constituição definitiva de acordos administrativos (suspensão de vistos em passaportes especiais ou diplomáticos, sobre malas e correios diplomáticos, sobre o regime de administração de pontes internacionais etc.). Isto posto, constata-se que, mesmo levando aos extremos a concepção de um poder regulamentar estritamente vinculado à lei, conforme é a concepção de PONTES DE MIRANDA, na esfera das relações interestatais o poder regulamentar existe, como definitiva forma de um poder normativo autônomo do Governo, no exercício do Poder Federativo (JOHN LOCKE), que se manifesta na comunidade dos Estados, como um monobloco, independentemente da tripartição do poder. Por sinal, é mesmo este poder normativo autônomo do Governo, que assegura a continuidade da política exterior dos Estados, que deve ser conduzida de tal molde, que os compromissos internacionais devam ser respeitados, bona fide, e que possibilita o crédito na ação do Estado, enquanto existente como tal, e seu efeito, junto as outras unidades políticas do Direito das Gentes.

\section{Bibliografia}

Accrolly, Hildebrando, A Ratificação e a Promulgação dos Tratados in Boletim da Sociedade Brasileira de Direito Internacional, n. ${ }^{\circ}$ 7, janeiro-junho de 1948.

Accioly, Hildebrando, Ainda o Problema da Ratificação dos Tratados, em face da Constituição Federal Brasileira in Boletim da Sociedade Brasileira de Direito Internacional, $n{ }^{0} 13 / 14$ (janeiro a dezembro), 1951. 
American Law Institute, Restatement, Second, Foreign Relations Law of the United States, as adopted and promulgated by, Washington D.C., 26 de maio de 1962 (revisões em 1964 e 1965), St. Paul Minn., American Law Institute Pub., 1965.

Albuquerque Melo, Celso D. De, Os Tratados na Constituição, apud Paulo BoNAvides et alii As Tendências Atuais do Direito Público, Estudos em Homenagem ao Professor Afonso Arinos de Melo Franco, Rio de Janeiro, Forense, 1976.

Basdevant, J., La Conclusion et la Rédaction des Traités Internationaux et des Instruments Diplomatiques autres que les Traités in Recueil des Cours da Academia de Direito Internacional da Haia, 1926, t. 17.

Blamont, Émile, Techniques Parlementaires in Politique et Technique Centre de Sciences Politiques de l'Institut d'Études Juridiques de Nice, Université d'Aix-Marseille, Paris, PUF, 1958.

BrasiL, Ministério das Relações Exteriores, Curso sobre Assuntos de Energia Nuclear, mimeo.

Duverger, Maurice, Constitutions et Documents Politiques, Paris, PuF, 6. ${ }^{2}$ Ed., 1971.

Ferreira Filho, Manoel Gonçalves, A Autonomia do Poder Regulamentar na Constituição Francesa de 1958, in Revista de Direito Administrativo, Rio de Janeiro, 1966, v. 84.

Ferreira Filho, Manoel Gonçalves, Comentários à Constituição Brasileira: Emenda Constitucional n. ${ }^{\circ} 1$ de 17 de outubro de 1969, São Paulo, 1. ${ }^{\text {a }}$ Ed., Saraiva, 1974.

Hamilton A., J. Madison e J. JAY, The Federalist Papers, The New American Library of World Literature, Mentor Book, Nova York, 1. ${ }^{\mathrm{a}}$ Ed., 1961 (com introdução e indexação de Clinont Rossiter).

Henkin, Louis, Foreign Affairs and the Constitution, Nova York, W. Norton \& Co. Inc. 1. ${ }^{\text {a }}$ Ed., 1972 (copyright da Foundation Press, Inc.).

KraUs, H. Système et Fonctions des Traitês Internationaux in Recueil des Cours da Academia de Direito Internacional da Haia, 1934, v. 50.

Lalive, Jean-Flfvien, Contracts between a State or a State Agency and a Foreign Company in 13 International and Comparative Law Quarterly, julho, 1974.

LibBRecht, Emmanuel, Entreprises à Caractère Juridiquement International, A. W. Sijthoff e Institut Universitaire de Hautes Études Internationales, respectivamente, Leiden e Genebra, 1972.

Maryan Green, N. A. International Law, Law of Peace, Londres, MacDonald \& Evans Ltd., 1973.

Melo Franco, Afonso ARINos, Poder Legislativo e Política Internacional in Estudos de Direito Constitucional, Rio de Janeiro, Ed. Revista Forense, 1957.

MerLe, MARCEL, L'Influence de la Technique sur les Institutions Politiques in Politique et Technique.

Nascimento e Silva, Geráldo Eulálio do, Direito Internacional no Projeto da Reforma da Constituição in Boletim da Sociedade Brasileira de Direito Internacional, n. $.^{\circ} 43 / 44$ (janeiro a dezembro), 1966. 
Pimenta Bueno, José Antonio, Direito Público e Análise da Constituição do Império, Brasil, Ministério da Justiça e dos Negócios Interiores, Serviço de Documentação, Rio de Janeiro, 1958.

Pontes de Miranda, Comentários à Constituição de 1967, com a Emenda $n .^{\circ} 1$, de 1969, tomo III (arts. 32-117), 2. ${ }^{\circledR}$ Ed. revista, São Paulo, Edit. Revista dos Tribunais.

Rodas, Joño Grandino, Os Acordos em forma simplificada in Revista da Faculdade de Direito, vol. LXVIII 1. ${ }^{\circ}$ fasc.) 1973, Universidade de São Paulo, São Paulo.

Serres, Jean, Manuel Pratique de Protocole, Editions de l'Arquebuse, 1. ${ }^{a}$ Ed., Vitry-le-François, Marne, 1965.

SIegrried, ANDRÉ, Le Problème de l'Etat au XXème Siécle en fonction de la production in Politique et Technique, Centre de Sciences Politiques de l'Institut d'Études Juridiques de Nice, Université d'Aix-Marseille, Paris, PUF, 1958.

SoARes, Guido Fernando Silva, O Acordo de Cooperação Nuclear Brasil-Alemanha Federal in Revista Forense n. ${ }^{0} 253$ (no prelo).

Soares, Guido Fernando Silva, Concessões de Petróleo e Arbitragens Internacionais, Coleção Jurídica JB, José Bushatsky Edit., São Paulo, 1977 (no prelo).

Soares, Guido Fernando Silva, As Salvaguardas nos Acordos Nucleares, Coleção Jurídica JB n. ${ }^{\circ}$ 17, São Paulo, Bushatsky, 1977 (no prelo).

Stadtmüller, Georg, História del Derecho Internacional Público, Madrid, Aguilar, Parte I, 1961.

Valladão, Haroldo, Parecer: Aprovação de Ajustes Internacionais pelo Congresso Nacional, in Boletim da Sociedade Brasileira de Direito Internacional, n. ${ }^{\circ} 11 / 12$ (janeiro a dezembro), 1950.

Verdross, Alfred, Derecho Internacional Público, Madri, Aguilar, 5. E Ed., 1967. 